\title{
Model Pembelajaran Berbasis Konflik Kognitif (PbKa)
}

UntulkIVIeninglkatkan Pemahaman Konsep dan IVeremediasilMislkonsepsi

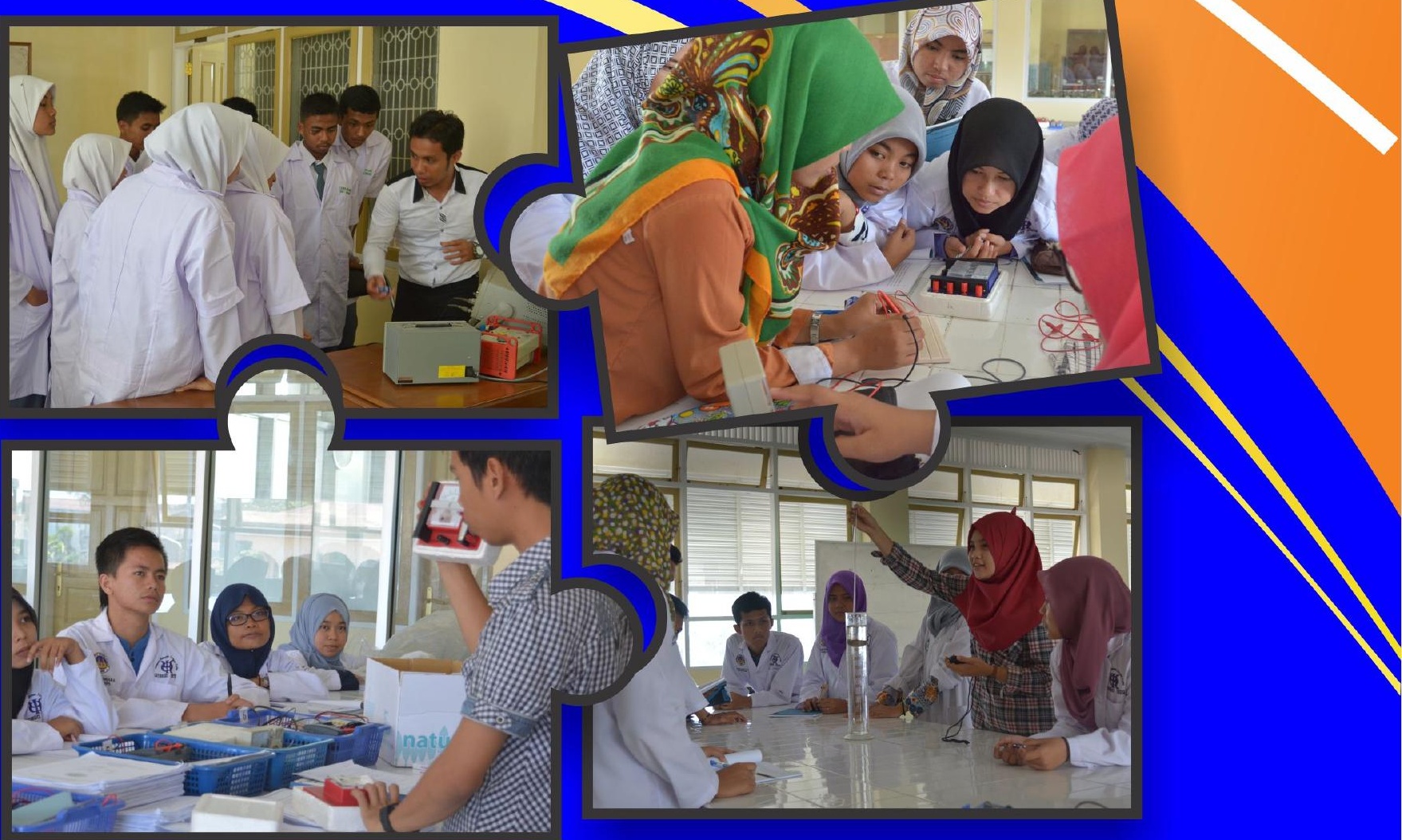

Patni Mugit

Universitas Negeri Padang

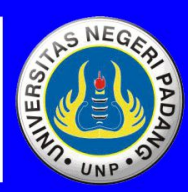


BUKU MODEL

\section{MODEL PEMBELAJARAN BERBASIS KONFLIK KOGNITIF (PbKK)}

Untuk Meningkatkan Pemahaman Konsep dan Meremediasi Miskonsepsi

\section{Penyusun \\ Fatni Mufit}




\section{PRAKATA}

Puji syukur kehadirat Allah SWT atas segala rahmat-NYA, sehingga penulis dapat menyelesaikan buku yang berjudul 'Model Pembelajaran Berbasis Konflik Kognitif (PbKK) untuk Meningkatkan Pemahaman Konsep dan Meremediasi Miskonsepsi'. Selanjutnya Shalawat dan Salam semoga tercurah kepada Rasulullah SAW yang membawa umatnya dari kejahiliyahan kepada cahaya islam dan ilmu pengetahuan.

Buku ini merupakan upaya dalam kepedulian dan keinginan berkontribusi terhadap peningkatan mutu pembelajaran, khususnya pembelajaran sains dalam mengatasi permasalahan pemahaman konsep mahasiswa. Pembelajaran sains terutama sains fisika dianggap sebagai pembelajaran yang sulit dipahami dan sarat dengan persamaan atau rumus. Hasil riset menunjukkan bahwa permasalahan miskonsepsi dan rendahnya pemahaman konsep menjadi permasalahan yang banyak terjadi dalam pembelajaran sains. Model pembelajaran berbasis konflik kognitif (PbKK) hadir sebagai salah satu model alternatif bagi para pendidik untuk meningkatkan pemahaman konsep dan meremediasi miskonsepsi.

Buku model pembelajaran berbasis konflik kognitif ( $\mathrm{PbKK})$ ini merupakan bagian dari produk disertasi penulis. Isi buku menjelaskan rasional dan hakikat model, teori pendukung model, karakteristik model serta petunjuk pelaksanaan model dalam pembelajaran. Model PbKK telah melalui serangkaian uji validitas, praktikalitas dan efektivitas, dan telah dinyatakan valid, praktis dan efektif dalam meningkatkan pemahaman konsep dan meremediasi miskonsepsi mahasiswa.

Penulis menyadari buku model pembelajaran ini masih banyak kekurangan, oleh karena itu kritik dan saran yang membangun diharapkan untuk perbaikan di masa yang akan datang. Akhir kata, semoga buku model pembelajaran berbasis konflik kognitif (PbKK) ini bermanfaat bagi penulis dan para pembaca serta berkontribusi dalam meningkatkan mutu pendidikan di Indonesia.

Padang, Agustus 2018

Penulis 


\section{DAFTAR ISI}

Hal

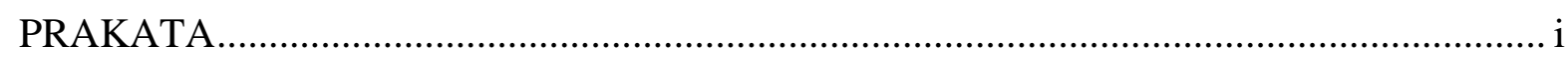

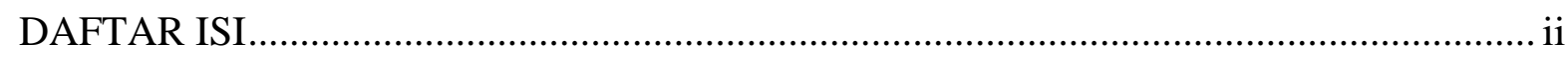

GAMBAR STRUKTUR MODEL PbKK...................................................................... iii

BAB 1. RASIONAL DAN HAKIKAT MODEL PbKK ....................................

BAB 2 TEORI BELAJAR PENDUKUNG MODEL PbKK .............................

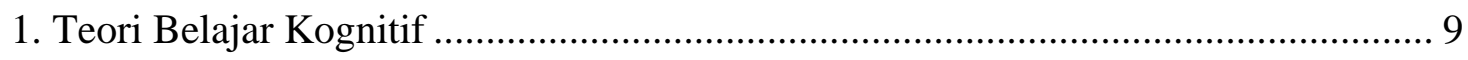

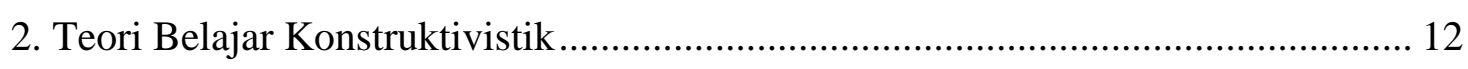

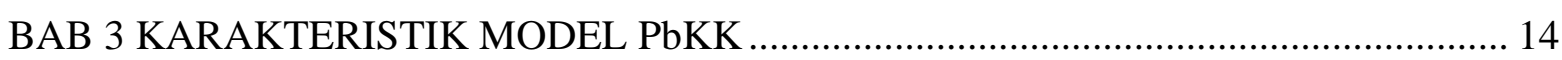

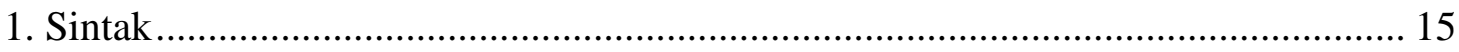

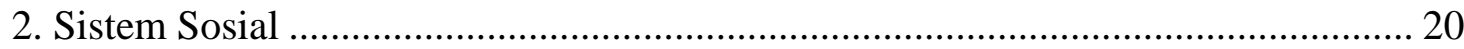

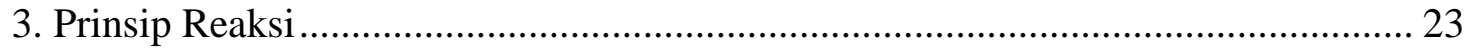

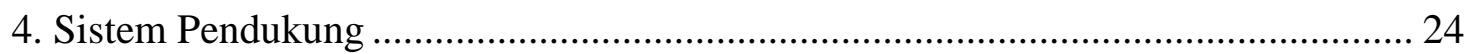

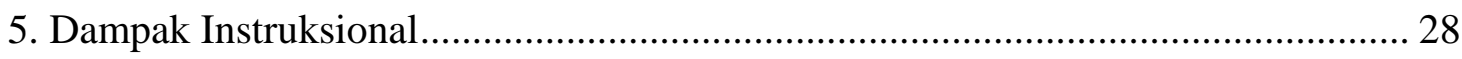

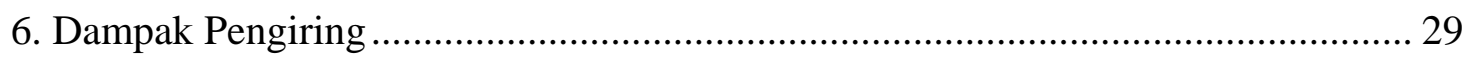

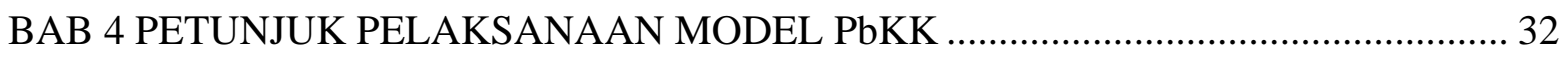

1. Petunjuk Pelaksanaan untuk Dosen ................................................................... 32

2. Sintak dan Kegiatan Pembelajaran dalam Penerapan Model ................................. 33

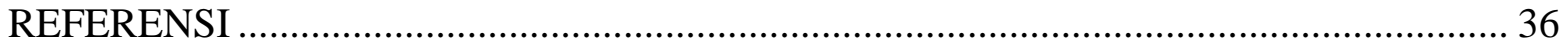




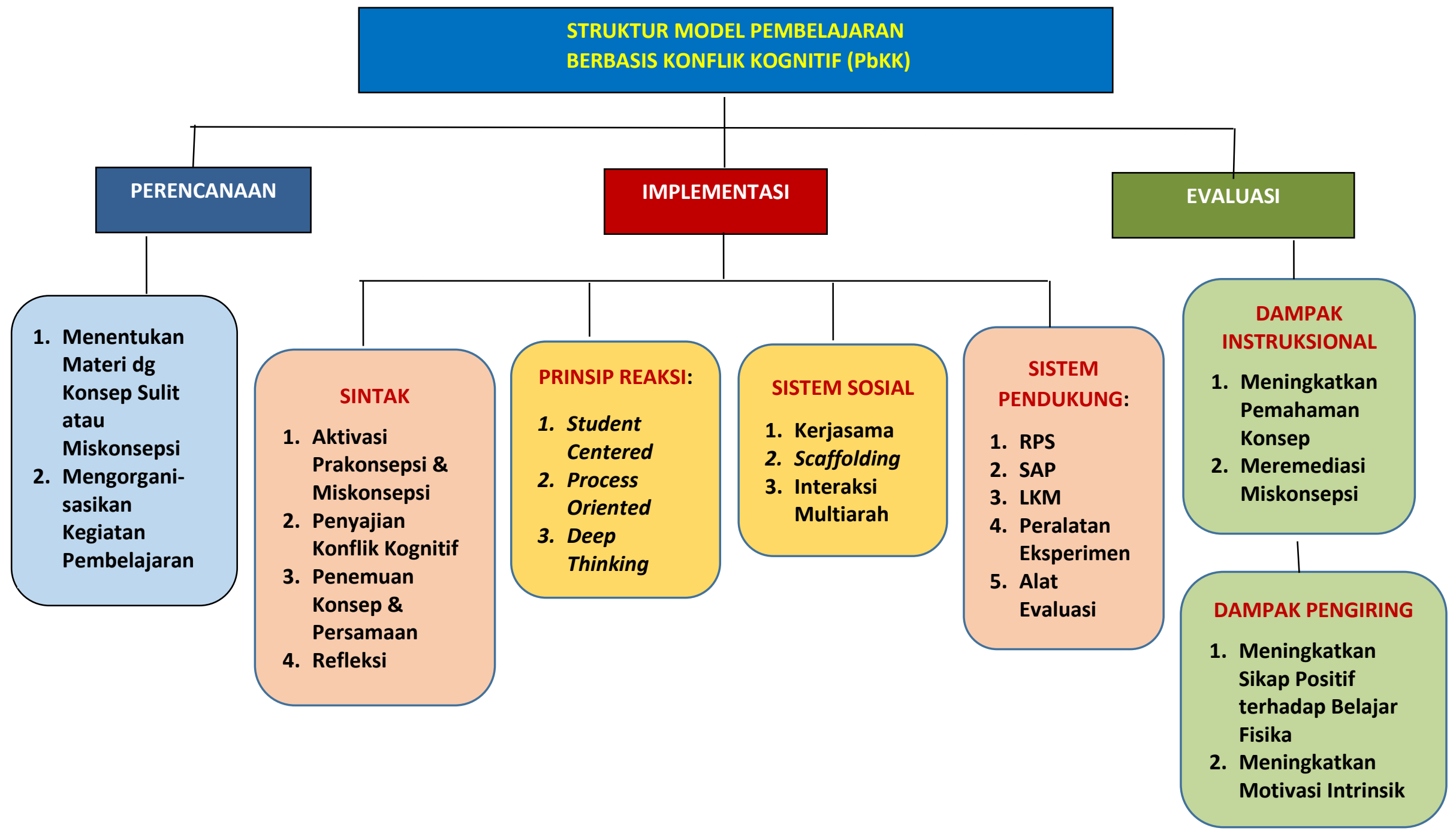




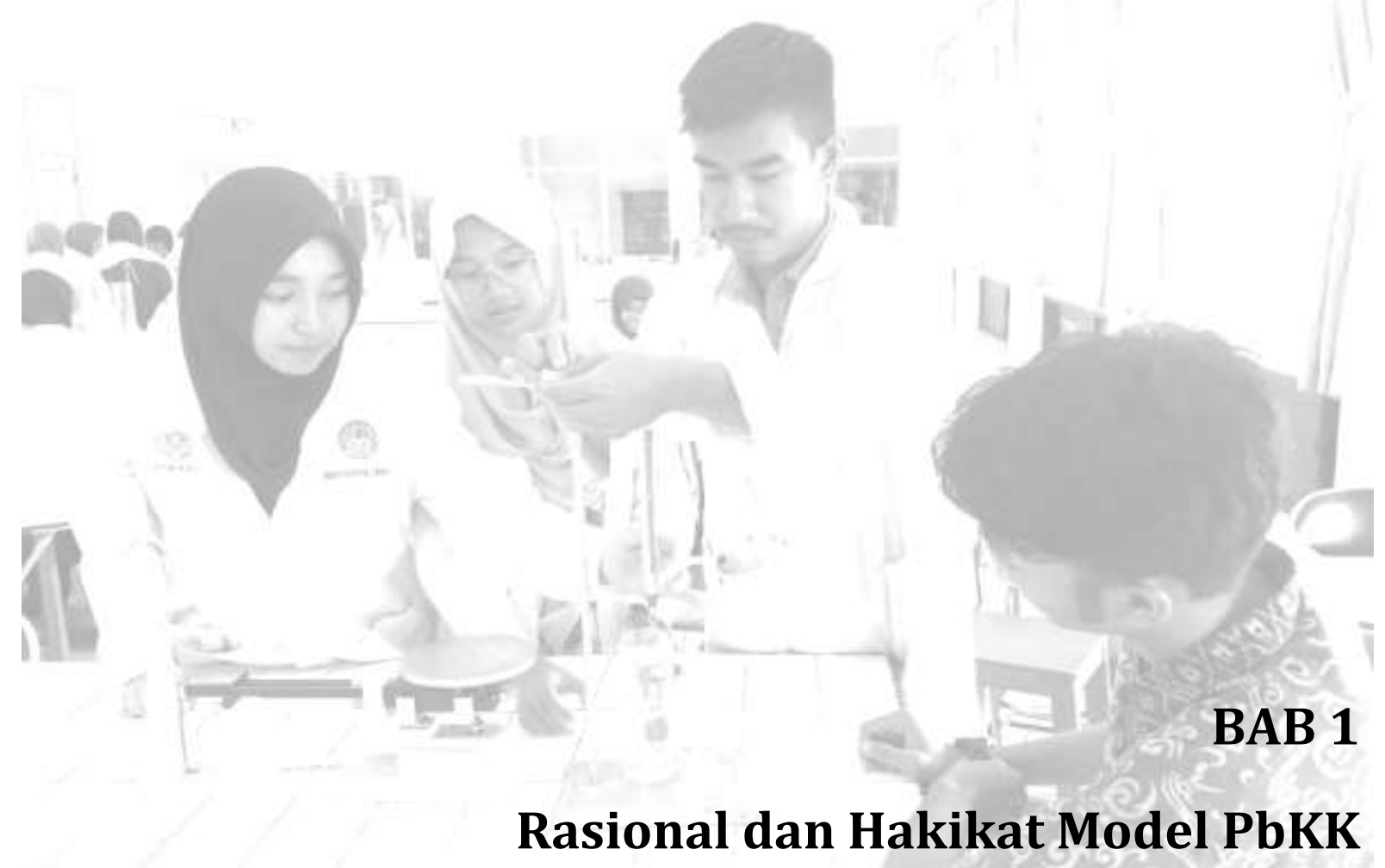

Model pembelajaran merupakan gambaran lingkungan agar siswa belajar dan sekaligus menggambarkan perilaku guru dalam menciptakan lingkungan atau kondisi belajar siswa. Reygeluth (1983) mengungkapkan: "an instructional model is usually an integrated set of strategy components, such as: the particular way the content ideas are sequenced, the use of overviews and summaries, the use of examples, the use of practice, and the use of different strategies for motivating the students". Menurut Reygeluth model pembelajaran merupakan seperangkat komponen strategi yang terintegrasi atau metode lengkap dengan semua bagian-bagiannya untuk memotivasi siswa mencapai tujuan pembelajaran. Sementara Arends, 1997 (dalam Al Tabany, 2014) menyatakan: "the term teaching model refers to a particular approach to instruction that includes its goals, syntax, environment and management system". Arends secara lebih luas mendeskripsikan model pembelajaran sebagai suatu pendekatan pembelajaran tertentu termasuk tujuannya, struktur atau sintaksnya, lingkungannya, dan sistem pengelolaannya. 
Berdasarkan beberapa pendapat para ahli, istilah model mengandung makna lebih luas daripada strategi, metode atau prosedur pembelajaran. Empat ciri khusus model pembelajaran yang tidak dimiliki oleh strategi, metode ataupun prosedur (Al Tabany, 2014), yaitu:

1) Rasional teoritik logis yang disusun oleh para pencipta atau pengembangnya.

2) Landasan pemikiran tentang apa dan bagaimana siswa belajar (tujuan pembelajaran yang akan dicapai)

3) Tingkah laku mengajar yang diperlukan agar model tersebut dapat dilaksanakan dengan berhasil

4) Lingkungan belajar yang diperlukan agar tujuan pembelajaran itu dapat tercapai.

Penciptaan suatu model mestilah dilandasi oleh teori belajar yang relevan dan model harus mempunyai tujuan pembelajaran yang jelas yang akan dicapai dengan menggunakan model tersebut. Selain itu, dalam model terkandung dengan jelas langkah-langkah yang akan dilakukan guru dalam menerapkan model, serta harus ada lingkungan belajar atau kondisi yang mendukung terlaksananya model.

Berdasarkan hasil pengamatan dan beberapa penelitian terhadap mahasiswa tahun pertama di Perguruan Tinggi, khususnya dalam matakuliah Fisika Umum (Mufit, 2016) diperoleh indikasi bahwa pemahaman konsep fisika mahasiswa sangat rendah dan sering terjadi miskonsepsi. Selain itu, mahasiswa merasa sulit memahami fisika dan mempunyai sikap yang kurang baik terhadap belajar fisika. Mereka menganggap fisika sebagai mata pelajaran yang sulit, sarat dengan persamaan atau rumus yang sulit dimengerti, serta memahami konsep fisika sebagai suatu hal yang terpisah dengan persamaan fisika. Diantara penyebab permasalahan tersebut adalah pembelajaran fisika yang dilakukan belum sepenuhnya berpusat pada mahasiswa, terutama dalam hal melibatkan mahasiswa secara aktif mengkonstruksi konsep. Model Pembelajaran yang ada belum memberikan perhatian secara khusus terhadap miskonsepsi yang dialami mahasiswa, serta belum mengoptimalkan kemampuan kognitif mereka dalam melakukan perubahan konseptual. 
Secara umum, belum banyak model pembelajaran yang memberi perhatian khusus terhadap pengetahuan awal (prakonsepsi ataupun miskonsepsi) mahasiswa, dan sekaligus meremediasi miskonsepsi tersebut melalui penemuan konsep dan persamaan. Model pembelajaran yang lazim digunakan pendidik adalah model pembelajaran langsung (Direct Instruction). Model ini lebih banyak memberikan pengetahuan deklaratif dan bersifat teacher center (Al Tabany, 2014). Model pengajaran langsung, sedikit sekali memberi ruang bagi mahasiswa untuk membangun sendiri konsep-konsep fisika mereka. Model lainnya yang umum digunakan adalah model pembelajaran kooperatif yaitu pembelajaran dengan penekanan pada kerjasama antar mahasiswa dalam menyelesaikan permasalahan fisika. Model ini dapat mengembangkan tingkah laku kooperatif dan kemampuan akademik mahasiswa (Ibrahim, 2000 dalam Al Tabany, 2014). Namun model ini belum efektif dalam meningkatkan pemahaman konsep fisika mahasiswa terutama dalam meremediasi miskonsepsi yang sering terjadi (Mufit, 2016). Begitu juga dengan model pembelajaran berbasis masalah, walaupun efektif untuk pembelajaran sains dengan proses berpikir tingkat tinggi dalam mengatasi permasalahan autentik mahasiswa, namun secara khusus model ini belum memuat langkah untuk mengungkap miskonsepsi mahasiswa dan meremediasi miskonsepsi yang terjadi.

Oleh karena itu, upaya yang diberikan terhadap permasalahan tersebut adalah dengan melakukan pengembangan model pembelajaran berbasis konflik kognitif (PbKK) untuk meningkatkan pemahaman konsep serta meremediasi miskonsepsi mahasiswa. Model berbasis konflik kognitif ini dirancang pengembangannya dari model pembelajaran berbasis masalah yang dikemukakan oleh Ronis (2001) sebagai model dasar, dan dikombinasikan dengan strategi konflik kognitif oleh Baser (2006). Kombinasi model pembelajaran berbasis masalah dengan strategi konflik kognitif ini diharapkan dapat mengatasi permasalahan miskonsepsi yang nyata dialami peserta mahasiswa, dengan melibatkan proses berpikir 
mendalam (deep thinking).

Rancangan model PbKK dapat dilihat pada Tabel 1.

Tabel 1. Rancangan Model Pembelajaran Berbasis Konflik Kognitif.

\begin{tabular}{cl}
\hline Tahap & \multicolumn{1}{c}{ Kegiatan } \\
\hline 1 & \multicolumn{2}{l}{ Mendesain Masalah: } \\
& a. $\quad$ Aktivasi prakonsepsi dan miskonsepsi \\
& b. $\quad$ Penyajian konflik kognitif \\
2 & Menemukan dan Mengidentifikasi Sumber Daya: \\
& c. $\quad$ Penemuan Konsep dan Persamaan (Eksperimen \& \\
& Menganalisis Masalah: \\
3 & d. $\quad$ Refleksi (Diskusi Kelas \& Evaluasi) \\
\hline
\end{tabular}

Rancangan model pembelajaran berbasis konflik kognitif disederhanakan penulisannya menjadi 4 tahap atau sintak seperti yang diperlihatkan pada Tabel 2.

Tabel 2. Sintak Model Pembelajaran Berbasis Konflik Kognitif.

\begin{tabular}{cl}
\hline $\begin{array}{c}\text { Tahap/ } \\
\text { Sintak }\end{array}$ & \multicolumn{1}{c}{ Kegiatan } \\
\hline 1 & Aktivasi prakonsepsi dan miskonsepsi \\
2 & Penyajian konflik kognitif \\
3 & Penemuan Konsep dan Persamaan \\
4 & Refleksi \\
\hline
\end{tabular}

Hakikat utama dalam model PbKK adalah berbasis pada strategi konflik kognitif sebagai pemicu munculnya perubahan konseptual, disamping adanya proses penemuan yang musti dilakukan peserta didik dalam model ini. Beberapa ahli telah melakukan penelitian tentang keunggulan strategi konflik kognitif dalam mengatasi miskonsepsi atau perubahan konseptual (Liang, 2016; Rahim, et.al, 2015; Sadia, 2014; Al Arief \& Suyono, 2012; Taufiq, dkk. 2011; Baser, 2006). Pada umumnya, strategi konflik kognitif mempunyai tiga bagian utama dalam melakukan perubahan konseptual, yaitu ada kegiatan pendahuluan, penyajian konflik dan penyelesaian konflik pada kognitif peserta didik. Model PbKK mengadopsi tiga 
langkah ini melalui tiga referensi utama dalam pengembangan model $\mathrm{PbKK}$, sebagaimana dapat dilihat pada Tabel 3.

Tabel 3. Rujukan Utama Pengembangan Model PbKK

\begin{tabular}{|c|c|c|}
\hline $\begin{array}{l}\text { Model Pembelajaran Konflik } \\
\text { Kognitif (Sadia, 2014) }\end{array}$ & $\begin{array}{c}\text { Implikasi Pembelajaran Konflik } \\
\text { Kognitif (Baser, 2006) }\end{array}$ & $\begin{array}{l}\text { Proses konflik kognitif } \\
\text { (Lee, 2003; dalam Mosik, }\end{array}$ \\
\hline 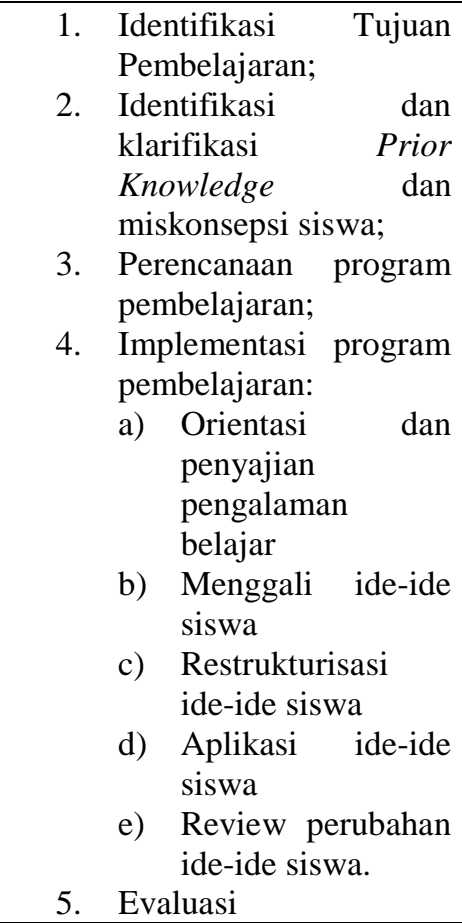 & $\begin{array}{l}\text { 1. Aktivasi konsepsi alternatif } \\
\text { siswa } \\
\text { 2. Penyajian situasi yang tidak } \\
\text { dapat dijelaskan dengan } \\
\text { konsep yang ada, } \\
\text { 3. Penciptaan konflik kognitif } \\
\text { dengan situasi anomali, } \\
\text { 4. Kebutuhan konsepsi lainnya } \\
\text { untuk menjelaskan situasi } \\
\text { anomali ini, } \\
\text { 5. Siswa mengkonstruksi } \\
\text { sendiri pengetahuan secara } \\
\text { aktif, } \\
\text { 6. Siswa berinteraksi satu } \\
\text { sama lain untuk berbagi } \\
\text { ide-ide mereka tentang } \\
\text { situasi anomali untuk } \\
\text { mencari solusi, dan } \\
\text { Tahu konsepsi sangat } \\
\text { membantu } \\
\text { memecahkan masalah yang } \\
\text { sama yang mungkin } \\
\text { dihadapi di masa depan. }\end{array}$ & 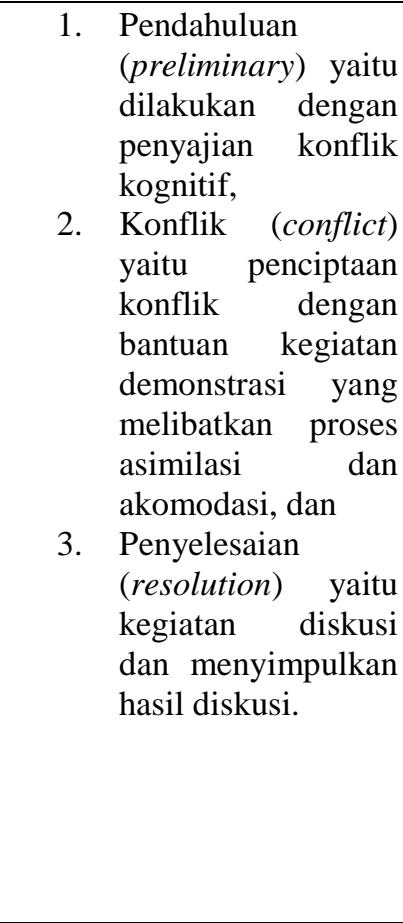 \\
\hline
\end{tabular}

Pada Tabel 3 dapat dilihat bahwa model yang dikemukakan Sadia mempunyai sintak yang cukup panjang untuk diaplikasikan oleh pendidik. Sintak lebih banyak menampilkan peran guru/pendidik dalam menyiapkan pembelajaran. Sintak ke-4 (implementasi program pembelajaran), merupakan inti proses konflik kognitif pada siswa, yang terdiri dari 5 langkah. Secara keseluruhan model pembelajaran konflik kognitif yang dikemukakan Sadia (2014) mempunyai 10 langkah. Peneliti mengembangkan model pembelajaran berbasis konflik kognitif (PbKK) dengan sintak model yang lebih sederhana, smart dan lebih fokus pada tahap ke-4 (implementasi) yang dikemukakan Sadia. 
Pada Implikasi pembelajaran konflik kognitif yang dikemukakan oleh Baser (2006), terdapat langkah yang menginspirasi untuk sintak pertama yaitu adanya aktivasi miskonsepsi peserta didik. Proses aktivasi penting dilakukan agar peserta didik menyadari miskonsepsi mereka dan memanggil kembali (recall) pemahaman konsep mereka yang sudah ada. Pada sintak awal ini, tidak hanya dilakukan proses identifikasi pengetahuan awal dan miskonsepsi oleh guru/pendidik, namun peserta didik juga perlu mengetahui dan menyadari miskonsepsi mereka melalui sintak aktivasi prakonsepsi dan miskonsepsi. Langkah 2-3 pada implikasi Baser menginspirasi pengembangan sintak ke-2 (penyajian konflik kognitif) dan langkah 4-6 menginspirasi sintak ke-3 (penemuan konsep dan persamaan). Proses penemuan pada sintak ke-3 dilakukan secara berkelompok atau berdiskusi sehingga terjadi interaksi dalam menggali ide, berbagi ide dan restrukturiasi ide antar peserta didik.

Pada Tabel 3, Lee mengemukakan 3 tahap utama yang umum ada pada setiap strategi pembelajaran konflik kognitif. Namun proses konflik kognitif yang dikemukakan Lee belum diawali dengan identifikasi atau aktivasi konsep awal atau miskonsepsi siswa. Sintak aktivasi prakonsepsi dan miskonsepsi penting dilakukan untuk merecall pengetahuan awal peserta didik dan sebagai bahan berpijak bagi pendidik dalam melakukan perubahan konseptual pada sintak berikutnya.

Tiga referensi pada Tabel 3 menjadi rujukan utama dalam mengembangan model pembelajaran berbasis konflik kognitif $(\mathrm{PbKK})$ beserta komponen model yang terdiri dari sintak, sistem sosial, prinsip reaksi, sistem pendukung, dampak instruksional serta dampak pengiring. Pada Tabel 4 juga disajikan referensi tambahan dalam penyusunan komponen model khususnya sintak model PbKK. 
Tabel 4. Sintak Model PbKK beserta Referensinya

\begin{tabular}{|c|c|}
\hline Sintak Model PbKK & Rujukan Literatur \\
\hline \multirow[t]{2}{*}{$\begin{array}{l}\text { 1. Aktivasi } \\
\text { Prakonsepai dan } \\
\text { Miskonsepsi. }\end{array}$} & $\begin{array}{l}\text { Kartal (2011): ketika memulai topik baru, hendaklah dilakukan } \\
\text { beberapa tes untuk mengetahui miskonsepsi yang dimiliki mahasiswa, } \\
\text { sehingga dosen mengetahui strategi dan metode yang tepat agar } \\
\text { konsep diterapkan dengan cara yang bermakna. }\end{array}$ \\
\hline & $\begin{array}{l}\text { Ormrod (2008): aktivasi pengetahuan awal (prior knowledge } \\
\text { activation) adalah proses mengingatkan peserta didik tentang hal-hal } \\
\text { yang telah mereka ketahui yang berkaitan dengan topik baru } \\
\text { merupakan upaya untuk mencapai pembelajaran bermakna } \\
\text { (meaningfull learning). }\end{array}$ \\
\hline \multirow[t]{3}{*}{$\begin{array}{l}\text { 2. Penyajian } \\
\text { Konflik Kognitif }\end{array}$} & $\begin{array}{l}\text { Trumper (2006): langkah awal yang diperlukan untuk perubahan } \\
\text { konseptual adalah memberi kesempatan peserta didik menyadari } \\
\text { perlunya perubahan konsep awal dan merasakan ketidakpuasan } \\
\text { terhadap pengetahuan sebelumnya. }\end{array}$ \\
\hline & $\begin{array}{l}\text { Meyer (2010): konflik konseptual adalah salah satu ide yang efektif } \\
\text { untuk membantu siswa untuk mengenali ketidakpuasan tersebut. }\end{array}$ \\
\hline & $\begin{array}{l}\text { Baser (2006); Lee et.al, } 2003 \text { (dalam Mosik 2010): ada tahap/ langkah } \\
\text { Penyajian Konflik kognitif }\end{array}$ \\
\hline \multirow[t]{3}{*}{$\begin{array}{l}\text { 3. Penemuan } \\
\text { Konsep } \\
\text { Persamaan. }\end{array}$} & $\begin{array}{l}\text { Al Tabany (2014): kegiatan penemuan sesuai dengan teori } \\
\text { konstruktivisme, yang menyatakan bahwa para peserta didik harus } \\
\text { menemukan sendiri dan mentransformasikan informasi kompleks, } \\
\text { mengecek informasi baru dengan aturan-aturan lama dan merevisinya } \\
\text { apabila aturan itu tidak sesuai lagi. }\end{array}$ \\
\hline & $\begin{array}{l}\text { Ormrod (2008): ketika peserta didik membentuk banyak hubungan } \\
\text { logis diantara berbagai konsep dan prinsip yang spesifik, maka mereka } \\
\text { mendapatkan pemahaman konseptual. }\end{array}$ \\
\hline & $\begin{array}{l}\text { Ormrod (2008): pengetahuan yang dikonstruksi secara sosial yang } \\
\text { dilakukan oleh dua orang atau lebih secara bersamaan akan lebih baik } \\
\text { dibanding konstruksi pengetahuan secara individual. }\end{array}$ \\
\hline \multirow[t]{2}{*}{ 4. Refleksi. } & $\begin{array}{l}\text { Presseisen, dkk, 1994, (dalam Ormrod, 2008): dialog kelas sangat } \\
\text { bermanfaat bagi pendidik, karena dengan memonitor komentar ataupun } \\
\text { pertanyaan mereka secara cermat, pendidik dapat mengidentifikasi dan } \\
\text { menyelesaikan kesalahpahaman (miskonsepsi) yang bisa menghambat } \\
\text { kemampuan mereka untuk memperoleh pengetahuan dan keterampilan } \\
\text { yang lebih luas lagi. }\end{array}$ \\
\hline & $\begin{array}{l}\text { Hacker dkk, 1998, (dalam Ormrod, 2008): peserta didik mampu } \\
\text { mengingat berbagai gagasan dan pengalaman baru secara lebih efektif } \\
\text { dan akurat ketika mereka membahas masalah secara bersama-sama } \\
\text { melalui diskusi kelas }\end{array}$ \\
\hline
\end{tabular}


Pada Tabel 2 juga terlihat teori yang mendukung sistem sosial (kerjasama, interaksi multiarah, deep thinking) dan prinsip reaksi (student centered, orientasi proses, scaffolding) dari model. Kerjasama dan interaksi multiarah dalam menemukan konsep dan persamaan dilakukan melalui kegiatan eksperimen dan diskusi kelompok pada sintak ketiga. Sementara itu, interaksi multiarah diperlukan saat diskusi kelas pada sintak ke-4 untuk mendapatkan balikan/ refleksi pembelajaran. Proses berpikir mendalam (deep thinking) diperlukan terutama pada sintak ke-3 dan ke-4. Pada sintak ini peserta didik mengalami ketidakpuasan, melakukan transformasi informasi komplek, membentuk banyak hubungan logis antar konsep dan prinsip melalui berpikir mendalam. Semua sintak model pembelajaran berbasis konflik kognitif $(\mathrm{PbKK})$ memerlukan keterlibatan peserta didik secara optimal (student centered) yang mengutamakan terjadinya proses pembelajaran (process oriented). Bantuan dosen sesuai kebutuhan mahasiswa (scaffolding) diperlukan khususnya pada sintak ke-3 dari model.

Model PbKK telah menjalani serangkaian uji untuk mengetahui tingkat validitas dan kepraktisan model, serta efektivitasnya dalam meningkatkan pemahaman konsep dan meremediasi miskonsepsi fisika mahasiswa. Berdasarkan hasil penelitian, diperoleh bahwa model PbKK mempunyai tingkat validitas dan kepraktisan yang sangat tinggi (Mufit dkk, 2018a), serta terbukti efektif dalam meningkatkan pemahaman konsep dan meremediasi miskonsepsi mahasiswa (Mufit dkk, 2018b). Model PbKK juga dapat meningkatkan sikap mahasiswa terhadap belajar fisika menjadi lebih baik, terutama sikap menyukai dan merasa senang belajar fisika. 


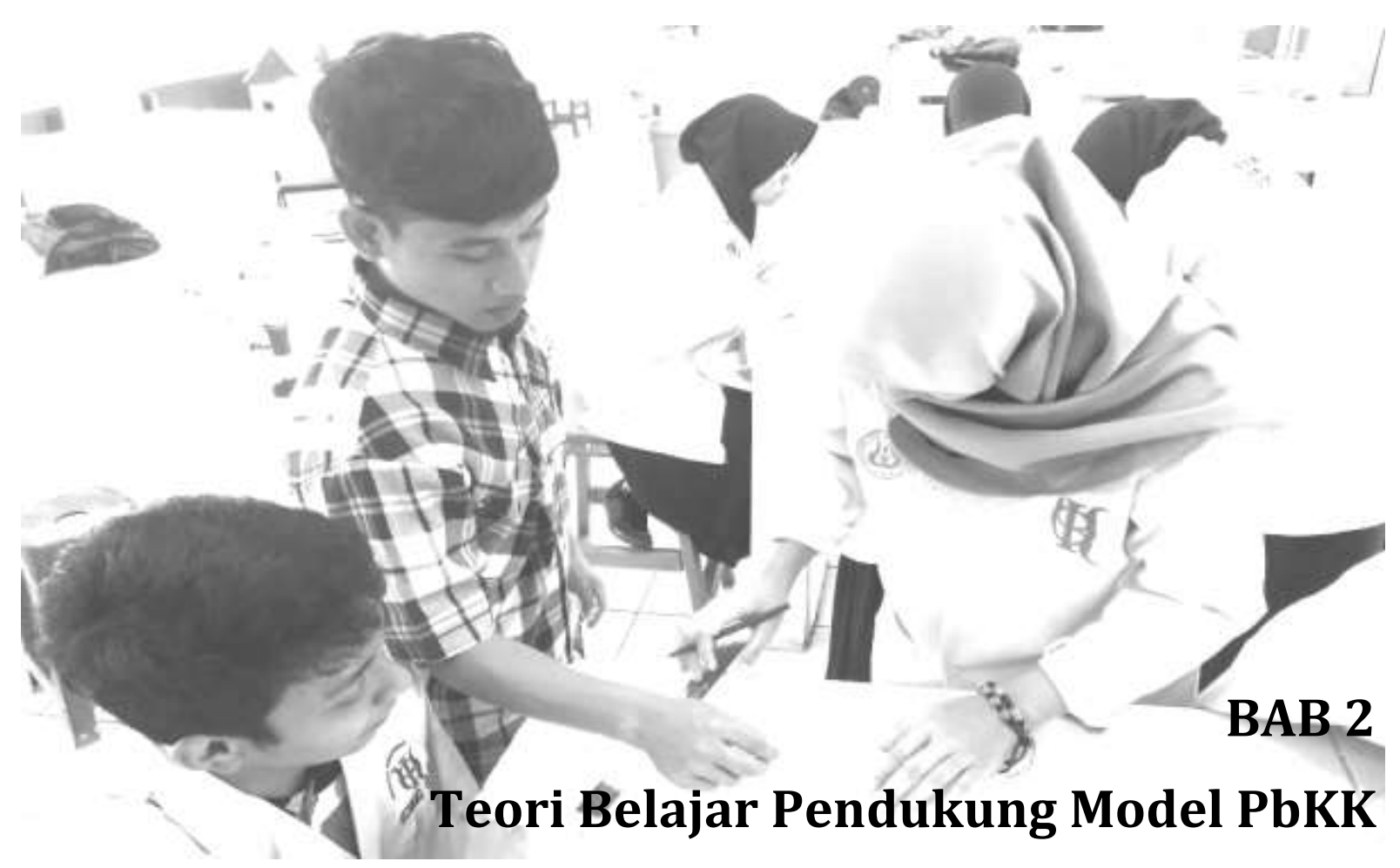

Teori belajar yang mendukung model pembelajaran berbasis konflik kognitif (PbKK) secara garis besar ada dua yaitu teori belajar Kognitif dan teori belajar Konstruktivistik. Teori belajar kognitif, memandang belajar sebagai kegiatan mental yang aktif untuk mencapai, mengingat dan menggunakan pengetahuan. Teori belajar konstruktivistik, memandang belajar sebagai kegiatan membangun pengetahuan oleh peserta didik itu sendiri. Teori belajar pada dasarnya merupakan penjelasan tentang bagaimana proses belajar terjadi dalam diri individu. Berikut ini penjelasan tentang kedua teori belajar yang melandasi strategi konflik kognitif.

\section{TeOri Belajar KognitiF}

Teori belajar kognitif memfokuskan pembahasan pada bagaimana peserta didik berpikir, memahami dan mengetahui. Dalam pandangan kognitif, belajar merupakan transformasi informasi atau ilmu pengetahuan yang ada di lingkungan, kemudian disimpan dalam pikiran (Baharuddin \& Wahyuni, 2015). Proses belajar terjadi ketika peserta didik memperoleh pengetahuan baru, atau perubahan dari pengetahuan lama melalui pengalamanpengalaman. Menurut teori ini, belajar adalah pengorganisasian aspek-aspek kognitif dan 
dan pemahamannya tentang situasi yang berhubungan dengan tujuan. Perubahan tingkah laku seseorang dipengaruhi oleh proses berfikir internal yang terjadi selama proses belajar.

\section{a. Teori Mengelola Informasi (Information Processing)}

Dalam aliran kognitif terdapat sejumlah teori, diantaranya teori mengelola informasi. Kegiatan memproses informasi dalam fikiran peserta didik meliputi: mengumpulkan dan menghadirkan informasi (encoding), menyimpan informasi (storage), dan menggali informasi kembali pada saat dibutuhkan (retrieval). Teori ini menjelaskan bagaimana pemrosesan, penyimpanan dan pemanggilan kembali pengetahuan dari otak.

Berdasarkan hasil penelitian dalam teori pemrosesan informasi didapatkan bahwa dasar pengetahuan yang baik lebih penting dari pada strategi belajar yang baik dalam memahami dan mengingat. Artinya seorang pendidik perlu mengetahui pengetahuan awal peserta didik sebelum proses belajar dimulai. Salah satu penyebab kesulitan peserta didik dalam belajar adalah tidak terjadi hubungan antara pengetahuan baru yang ia terima dengan pengetahun awal yang dimiliki. Oleh karena itu, pengetahuan awal menjadi syarat utama dan penting bagi peserta didik dalam belajar. Nur, 2000 (dalam Al Tabany, 2014) menyatakan bahwa: "pengetahuan awal (prior knowledge) adalah sekumpulan pengetahuan dan pengalaman individu yang diperoleh sepanjang perjalanan hidup mereka, dan apa yang ia bawa pada suatu pengalaman belajar baru". Pengetahuan awal ini yang sering menjadi miskonsepsi bagi peserta didik, dan diperlukan tindakan untuk meremediasinya, salah satunya melalui strategi konflik kognitif.

\section{b. Teori Belajar Bermakna (Meaningfull Learning)}

Dalam teori belajar kognitif juga terdapat Teori Belajar Bermakna, yang dikemukakan oleh David Ausubel. Belajar bermakna merupakan suatu proses dikaitkannya informasi baru pada konsep-konsep relevan yang terdapat dalam struktur kognitif seseorang (Dahar, 2011). 
Struktur kognitif dapat berupa fakta, konsep dan generalisasi yang telah dipelajari dan diingat oleh peserta didik. Belajar bermakna tidak terjadi jika peserta didik tidak mengaitkan informasi atau konsep yang ada dalam struktur kognitifnya, dalam hal ini yang terjadi adalah belajar hafalan. Inti dari teori belajar bermakna Ausubel adalah konsep baru atau informasi baru harus dikaitkan dengan konsep yang sudah ada dalam struktur kognitif peserta didik. Teori ini menunjukkan pentingnya peran pengetahuan awal dalam proses belajar peserta didik.

\section{c. Teori Belajar Penemuan (Discovery Learning)}

Teori Belajar Penemuan dikemukakan oleh Jerome Brunner, yang menyatakan bahwa belajar penemuan merupakan pencarian pengetahuan secara aktif oleh manusia. Pembelajar berusaha sendiri mencari pemecahan masalah serta pengetahuan yang menyertainya, menghasilkan pengetahuan yang benar-benar bermakna (Dahar, 2011). Belajar penemuan memberikan pengalaman kepada pembelajar dan melakukan eksperimen agar mereka menemukan sendiri konsep dan prinsip secara aktif.

Ada tiga keutamaan belajar penemuan, yaitu; (1) pengetahuan akan bertahan lama dan mudah diingat dibanding belajar dengan cara lain, (2) Hasil belajar penemuan mempunyai efek transfer yang lebih baik dari pada hasil belajar yang lain. Artinya konsep dan prinsip yang diperoleh dari hasil penemuan lebih mudah diterapkan pada situasi baru, (3) Belajar penemuan meningkatkan penalaran pembelajar dan kemampuan untuk berpikir secara bebas (Dahar, 2011). Belajar penemuan akan melatih kemampuan kognitif pembelajar dalam menemukan dan memecahkan masalah tanpa batuan orang lain.

Salah satu peran guru dalam belajar penemuan adalah menyajikan materi sebagai dasar bagi pembelajar untuk memecahkan masalah secara aktif. Guru hendaknya memulai dengan sesuatu yang telah dikenal pembelajar, kemudian guru mengemukakan sesuatu yang berlawanan sehingga terjadi konflik dengan pengalaman siswa (Dahar, 2011). Teori inilah 
yang mendasari model pembelajaran berbasis konflik kognitif, yang diawali dengan mengaktifkan prakonsepsi atau miskonsepsi mahasiswa untuk memunculkan masalah. Selanjutkan penyajian fenomena konflik kognitif yang berlawanan dengan miskonsepsi mahasiswa, untuk memicu berpikir mendalam dan merangsang rasa ingin tahu, dan akhirnya mahasiswa berusaha menyelidiki dan menemukan konsep dan prinsip yang mendasari masalah.

\section{TEORI BELAJAR KONSTRUKTIVISTIK}

Teori Belajar Konstruktivisme menyatakan bahwa pengetahuan dibangun dalam pikiran peserta didik. Menurut teori konstruktivisme, peserta didik harus menemukan sendiri dan mentransformasikan informasi kompleks, mengecek informasi baru dengan aturan-aturan lama dan merevisinya apabila aturan itu tidak sesuai lagi (Al Tabany, 2014). Shymansky dan Kyle, 1992 (dalam Sadia, 2014) menyatakan bahwa belajar menurut para penganut konstruktivistik adalah pengkonstruksian pengetahuan oleh individu-individu sebagai pemberian makna atas dasar sensori dalam hubungannya dengan pengetahuan sebelumnya (prior knowledge). Dalam teori konstruktivistik, peserta didik harus membangun sendiri pengetahuan dalam benaknya dan menghubungkan dengan pengetahuan awal. Tugas pendidik memfasilitasi dan memberikan kemudahan dengan memberikan kesempatan peserta didik menemukan dan menerapkan ide-ide mereka sendiri dalam proses belajar.

Salah satu prinsip utama dalam teori konstruktivisme adalah pengetahuan atau konsep baru dibangun di atas pengetahuan atau konsep sebelumnya (Davis \& Vinner, 1986; Hewson \& Hewson, 1984; Meyer, 1993, dalam Liang, 2016). Filsafat konstruktivisme secara singkat juga menyatakan bahwa pengetahuan dibangun (konstruk) oleh peserta didik melalui kontak dengan lingkungan, tantangan dan bahan yang dipelajari (Suparno, 2013). Oleh karena itu, pendidik perlu menyadari bahwa peserta didik sudah mempunyai pengetahuan awal sebelum mereka mempelajari konsep atau pengetahuan baru. Berdasarkan pengetahuan awal inilah 
pendidik membelajarkan peserta didik untuk membangun sendiri pengetahuan mereka melalui berbagai kegiatan/ pengalaman belajar.

\section{Teori Pembelajaran Sosial Vigotsky}

Perspektif konstruktivis baru juga mengikutsertakan proses-proses sosial dalam konstruksi pengetahuan oleh peserta didik, yang dikenal teori pembelajaran sosial Vigotsky. Menurut Vigotsky (dalam Al Tabany, 2014), proses pembelajaran akan terjadi jika peserta didik bekerja atau menangai tugas-tugas yang belum dipelajari, namun tugas-tugas tersebut masih berada dalam jangkauan mereka, yang disebut zone of proximal development $(Z P D)$, yaitu daerah tingkat perkembangan sedikit diatas daerah perkembangan seseorang saat ini. Fungsi mental yang lebih tinggi akan muncul dalam percakapan dan kerjasama antar individu. Vigotsky juga mengemukakan ide penting lainnya yaitu Scaffolding, adalah pemberian bantuan terhadap peserta didik selama tahap-tahap awal perkembangannya, dan mengurangi bantuan itu serta memberi kesempatan kepada peserta didik untuk mengambil alih jika mereka sudah dapat melakukannya.

Ide Vigotsky ini penting dalam pengembangan model pembelajaran berbasis konflik kognitif, dalam hal ini pendidik merancang pembelajaran yang melibatkan kerja sosial peserta didik dalam memahami dan merubah miskonsepsi mereka. Interaksi sosial (atau interaksi teman sebaya) dan diskusi kelompok merupakan faktor penting dalam perubahan konseptual, sebagai penegasan dari konstruktivisme sosial (e.g., Uzuntiryaki, 2003; Brophy, 1986; Vygotsky, 1978, dalam Baser, 2006). Menurut pendekatan belajar konstruktivistik, pengetahuan dikonstruksi secara sosial (Duit, 2002) dan motivasi intrinsik dapat dihasilkan melalui diskusi kelompok, yang berperan penting dalam konstruksi pengetahuan (Pintrich, Marx, \& Boyle, 1993, dalam Baser, 2006). Pemberian fenomena konflik kognitif serta pemberian bantuan (scaffolding) sesuai dengan perkembangan mahasiswa tahun pertama dalam mengkonstruksi pengetahuan baru dan meremediasi miskonsepsi mereka. 


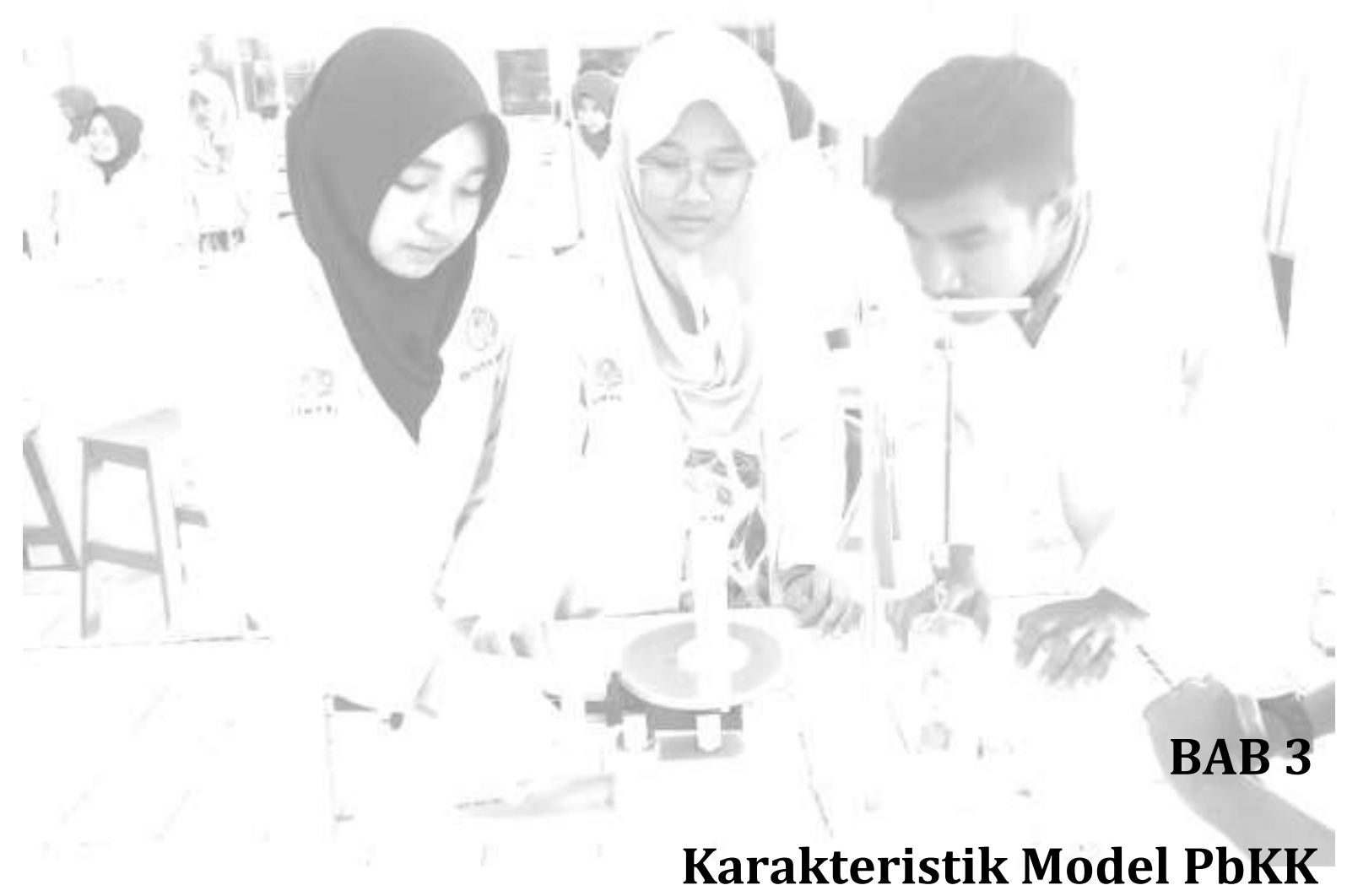

Karakteristik model menyatakan ciri-ciri khusus model yang membedakannya dengan model lainnya. Karakteristik model pembelajaran dapat dilihat pada komponenkomponen model, terutama sintak model. Menurut Joyce \& Weil (1980) model pembelajaran memiliki lima komponen dasar, yaitu (1) sintak (syntax), adalah urutan atau langkah-langkah operasional pembelajaran, (2) sistem sosial (social system), menggambarkan peran pendidik dan peserta didik, hubungan hirarki dan aturan-aturan berdasarkan peran tersebut, (3) prinsip-prinsip reaksi (principles of reaction), merupakan gambaran bagaimana seharusnya guru memandang, memperlakukan, dan merespon peserta didik, (4) sistem pendukung (support system), yaitu segala sarana, bahan, alat, atau lingkungan belajar yang mendukung pembelajaran, dan (5) dampak instruksional dan dampak pengiring, merupakan hasil belajar yang diperoleh langsung berdasarkan tujuan yang disasar (instructional effects) dan hasil belajar di luar yang disasar (nurturant effects). 


\section{SINTAK}

Model pembelajaran berbasis konflik kognitif yang dirancang ini terdiri dari empat sintak (fase/tahap), yaitu: (1) Aktivasi Prakonsepsi dan Miskonsepsi, (2) Penyajian Konflik Kognitif, (3) Penemuan Konsep dan Persamaan, (4) Refleksi. Masing-masing sintak dijelaskan sebagai berikut:

\section{a. Tahap 1: Aktivasi Prakonsepsi dan Miskonsepsi}

Tahap ini bertujuan untuk mengetahui pengetahuan awal mahasiswa (prior knowledge) sebelum dimulai pembelajaran. Prakonsepsi adalah pengetahuan atau konsep awal yang dipunyai peserta didik sebelum dilakukan pembelajaran. Prakonsepsi yang tidak sesuai dengan penelitian ilmiah yang dikemukakan oleh para ahli dikenal dengan miskonsepsi. Fowler, 1987 (dalam Suparno, 2013) menjelaskan miskonsepsi sebagai pengertian yang tidak akurat akan konsep, penggunaan konsep yang salah, klasifikasi contoh-contoh yang salah, kekacauan konsep-konsep yang berbeda, dan hubungan hirarkis konsep-konsep yang tidak benar. Di dalam fisika, miskonsepsi dapat diartikan sebagai penggunaan konsep fisika yang tidak sesuai dengan konsep yang dinyatakan oleh para ahli atau ilmuwan fisika yang sudah diterima secara ilmiah.

Menurut Clement, 1987 (dalam Suparno, 2013) miskonsepsi yang paling banyak terjadi bukan karena salah pengertian selama proses belajar, namun suatu konsep awal (prakonsepsi) yang diperoleh siswa saat berinteraksi dengan lingkungan dan konsep tersebut mereka bawa ke dalam kelas formal. Siswa secara kontinu sudah mengkonstruksi konsepkonsep melalui pengalaman hidup mereka di luar kelas formal. Fenomena miskonsepsi ini terjadi hampir di setiap jenjang pendidikan, bahkan menurut Wilardjo (2009), walaupun jumlah peserta didik yang mengalami miskonsepsi cenderung menurun dengan bertambahnya usia mereka dan makin tinggi jenjang pendidikan mereka, namun diantara mereka masih mengidap miskonsepsi sampai di perguruan tinggi bahkan setelah menjadi sarjana. 
Aktivasi prakonsepsi dan miskonsepsi sebelum memulai pembelajaran, penting dilakukan agar pendidik dapat memberikan tindakan yang tepat dalam membelajarkan peserta didik. Selain itu peserta didik juga mengetahui bahwa ternyata selama ini mereka mempunyai konsep yang salah yang harus diperbaiki. Aktivasi pengetahuan awal (prior knowledge activation) adalah proses mengingatkan peserta didik tentang hal-hal yang telah mereka ketahui yang berkaitan dengan topik baru (Ormrod, 2008). Aktivasi pengetahuan awal ini merupakan upaya untuk mencapai pembelajaran bermakna (meaningfull learning), yaitu suatu proses kognitif bagi peserta didik untuk mengaitkan informasi baru dengan halhal yang sudah mereka ketahui. Pembelajaran bermakna ini jelas lebih efektif dari pada pembelajaran hafalan (Ausubel, dkk. 1978, dalam Ormrod, 2008). Tahap aktivasi prakonsepsi dan miskonsepsi ini dilaksanakan dengan bantuan LKM yang berisi pertanyaan tentang konsep-konsep materi yang akan dipelajari.

\section{b. Tahap 2: Penyajian Konflik Kognitif}

Penyajian fenomena konflik kognitif pada tahap ini bertujuan agar terjadi konflik konseptual pada diri peserta didik sebelum mereka melakukan proses perubahan konseptual untuk menemukan konsep baru yang benar secara ilmiah. Pada tahap kedua ini, melalui sajian fenomena fisika yang memicu konflik kognitif, peserta didik juga diminta memprediksi kejadian dengan memberikan jawaban sementara dari setiap pertanyaan tentang konsepkonsep fisika. Brown, dkk, 1994 (dalam Ormrod, 2008) menyatakan bahwa meminta peserta didik membuat prediksi sebelumnya dapat mengaktivasi kepercayaan dan ketidakpercayaan yang ada. Prediksi sebelum tahap penemuan penting dilakukan untuk menimbulkan kepercayaan peserta didik untuk menemukan konsep-konsep dan keterkaitan konsep melalui persamaan. Peran dosen penting dalam tahap ini dalam menyajikan fenomena konflik kognitif yang berlawanan dengan miskonsepsi mahasiswa. Tahap ini juga dibantu dengan 
LKM yang menyajikan fenomena fisika beserta pertanyaan, dan mahasiswa memberikan jawaban sementara untuk memicu konflik kognitif dan rasa ingin tahu.

Berdasarkan hasil penelitian Tarigan (2013), yang mengungkapkan bahwa strategi membangkitkan konflik kognitif, dapat dilakukan dengan cara membandingkan konflik atau pertentangan dalam diri siswa; merupakan strategi yang disarankan dalam perubahan konseptual. Perubahan konseptual diperlukan untuk mengubah prakonsepsi peserta didik yang tidak sesuai dengan konsep ilmiah (miskonsepsi). Menurut Trumper, 1997 (dalam Liang, 2016); langkah awal yang diperlukan untuk perubahan konseptual adalah memberi kesempatan peserta didik menyadari perlunya perubahan konsep awal tersebut dan merasakan ketidakpuasan dengan penjelasan yang didasarkan pada pengetahuan sebelumnya. Konflik konseptual adalah salah satu ide yang efektif untuk membantu siswa untuk mengenali ketidakpuasan tersebut (Meyer, 1993, dalam Liang, 2016).

\section{c. Tahap 3: Penemuan Konsep dan Persamaan}

Tahap penemuan konsep dan persamaan bertujuan untuk mencapai pemahaman konseptual yang bertahan lama dalam ingatan mahasiswa. Tahap penemuan konsep juga bertujuan agar mahasiswa tidak memisahkan antara persamaan fisika dengan konsep yang terkandung di dalamnya. Penemuan konsep dan persamaan dilakukan secara berkelompok melalui kegiatan eksperimen dan diskusi kelompok. Pembagian kelompok dilakukan secara heterogen berdasarkan kemampuan belajar mahasiswa. LKM berperan penting dalam tahap ini yang akan memandu mahasiswa melakukan eksperimen dan diskusi kelompok. Peralatan eksperimen yang dibutuhkan juga penting dalam mendukung terlaksananya tahap ini, oleh karena itu perlu disiapkan sebelum memulai pembelajaran.

Kegiatan 'penemuan', sesuai dengan teori konstruktivisme, yang menyatakan bahwa para peserta didik harus menemukan sendiri dan mentransformasikan informasi kompleks, mengecek informasi baru dengan aturan-aturan lama dan merevisinya apabila aturan itu tidak 
sesuai lagi (Al Tabany, 2014). Dalam proses penemuan ini, mahasiswa membangun pengetahuannaya yang baru dan menghubungkannya dengan pengetahuan sebelumya (prior knowledge) baik berupa prakonsepsi maupun miskonsepsi.

Pada tahap ini, mahasiswa tidak hanya menemukan konsep, namun juga menemukan persamaan matematis yang menjelaskan tentang hubungan antar konsep- konsep yang telah mereka temukan sebelumnya. Proses penemuan konsep dan sekaligus mengorganisasikan konsep-konsep tersebut dalam bentuk persamaan matematis merupakan upaya mencapai pemahaman konseptual (conceptual understanding). Ketika peserta didik membentuk banyak hubungan logis diantara berbagai konsep dan prinsip yang spesifik, maka mereka mendapatkan pemahaman konseptual (Ormrod, 2008).

Menemukan hubungan logis beberapa konsep dan prinsip fisika yang membentuk suatu persamaan fisika, jelas lebih baik dari pada peserta didik tersebut menghafal begitu saja suatu persamaan fisika. Penemuan konsep sekaligus hubungan logis yang membentuk persamaan ini penting dilakukan agar mahasiswa tidak memisahkan antara persamaan (rumus) fisika dengan konsep fisika yang terkandung di dalam persamaan tersebut. Dengan demikian, mahasiswa tidak lagi memandang bahwa persamaan (rumus) fisika sebagai suatu operasi matematis yang berdiri sendiri, yang hanya dihafal tanpa tahu makna fisis yang terkandung di dalamnya. Tahap ini juga sebagai upaya agar mahasiswa tidak bersikap negatif terhadap pelajaran fisika dengan menganggap bahwa fisika itu sulit, yang sarat dengan rumus-rumus tanpa makna fisis.

Penemuan konsep dan persamaan dilakukan secara berkelompok atau saling kerjasama antar mahasiswa. Ormrod (2008) menyatakan bahwa pengetahuan yang dikonstruksi secara sosial yang dilakukan oleh dua orang atau lebih secara bersamaan akan lebih baik dibanding konstruksi pengetahuan secara individual. Mengkonstruksi pengetahuan secara sosial 
melibatkan peserta didik bekerja sama secara aktif untuk mendapatkan pemahaman yang lebih baik tentang berbagai informasi dan peristiwa.

\section{d. Tahap 4: Refleksi}

Pada tahap keempat yaitu refleksi, bertujuan agar pendidik dapat menilai sejauh mana tingkat pemahaman konsep peserta didik setelah melakukan tahap penemuan konsep dan persamaannya. Refleksi pertama dilakukan melalui kegiatan diskusi kelas tentang kegiatan penemuan yang telah dilakukan pada tahap ketiga. Salah satu kelompok mempresentasikan hasil kerjanya, lalu kelompok lain menanggapi permasalahan ataupun kesamaan atau perbedaan hasil yang mereka dapatkan selama kegiatan penemuan. Dialog kelas yang terjadi selama proses diskusi kelas akan menjadi balikan bagi pendidik untuk mengetahui sejauh mana pemahaman konsep peserta didik maupun miskonsepsi yang masih terjadi. Sebagaimana Presseisen, dkk, 1994, (dalam Ormrod, 2008) menyatakan bahwa dialog kelas sangat bermanfaat bagi pendidik, karena dengan memonitor komentar ataupun pertanyaan mereka secara cermat, pendidik dapat mengidentifikasi dan menyelesaikan kesalahpahaman (miskonsepsi) yang bisa mengahambat kemampuan mereka untuk memperoleh pengetahuan dan keterampilan yang lebih luas lagi.

Selain sebagai balikan bagi pendidik, diskusi kelas juga memperkuat pemahaman konsep peserta didik melalui dialog kelas karena terjadi proses konstruksi pemahaman secara menyeluruh. Pengalaman selama kegiatan penemuan oleh masing-masing kelompok akan terungkap selama diskusi kelas, dan masing-masing kelompok akan saling berbagi pengalaman yang akan memperkaya pengetahuan mereka. Hacker dkk, 1998, (dalam Ormrod, 2008) menyatakan bahwa peserta didik mampu mengingat berbagai gagasan dan pengalaman baru secara lebih efektif dan akurat ketika mereka membahas masalah secara bersama-sama melalui diskusi kelas. Oleh karena itu, para ahli kontemporer merekomendasikan agar kegiatan diskusi kelas dilakukan secara rutin dalam kegiatan 
pembelajaran. Saat diskusi kelas ini pendidik dapat memberikan balikan secara langsung jika terjadi miskonsepsi atau konsep yang tidak dipahami dengan baik.

Pada tahap ini, refleksi tentang pemahaman konsep peserta didik juga diketahui melalui soal evaluasi yang diberikan dan diselesaikan oleh peserta didik secara individu. Soal evaluasi menuntut pemahaman konsep dan sekaligus pemahaman tentang kaitan antar konsep melalui persamaan matematisnya. Hasil kerja peserta didik dalam menyelesaikan soal evaluasi dapat menjadi balikan bagi pendidik untuk mengetahui tingkat pemahaman dan miskonsepsi yang masih terjadi setelah proses pembelajaran selesai dilakukan. Soal- soal evaluasi difasilitasi menggunakan LKM, disusun sesuai dengan indikator pembelajaran.

\section{SISTEM SOSIAL}

Sistem sosial menggambarkan peran pendidik dan peserta didik, hubungan hirarki dan aturan-aturan berdasarkan peran tersebut. Model pembelajaran berbasis konflik kognitif lebih banyak menuntut adanya kerjasama antara pembelajar dalam menemukan konsep dan persamaan fisika melalui kegiatan eksperimen maupun diskusi kelompok. Interaksi multi arah antar sesama pembelajar maupun pembelajar dengan pendidik sangat dibutuhkan terutama pada tahap penemuan (eksperimen dan diskusi kelompok) serta tahap refleksi (diskusi kelas). Peran pendidik terutama dalam mengaktifkan dan mengidentifikasi miskonsepsi pembelajar, penyajian konflik kognitif serta memberikan scaffolding dalam proses penemuan. Sistem sosial ini dijelaskan secara lebih rinci sebagai berikut:

\section{a. Kerjasama}

Pada model pembelajaran berbasis konflik kognitif ini, kerjasama dilakukan pada tahap ke tiga, yaitu kerjasama dalam menemukan konsep dan persamaannya. Melalui kerjasama dan diskusi kelompok, mahasiswa akan merasakan manfaat kognitif, dengan adanya keterlibatan mahasiswa dalam pendistribusian kognisi (distributed cognition). Ormrod (2008) 
menyatakan pendistribusian kognisi adalah: suatu proses dimana para mahasiswa memikirkan suatu isu atau peristiwa secara bersama-sama dengan saling berbagi gagasan dan bekerja secara kolaboratif untuk menarik kesimpulan atau memberikan solusi.

Kerjasama dan diskusi kelompok antar mahasiswa tidak hanya memberikan manfaat kognitif, namun juga manfaat sosial dan motivasional. Keterampilan intrapersonal mahasiswa menjadi lebih efektif dengan berdiskusi kelompok dan juga mendatangkan efek motivasi yang membangkitkan semangat, terutama dalam memecahkan topik-topik yang kontroversial. Chinn, 2006 (dalam Ormrod, 2008) menyatakan bahwa topik-topik kontroversial secara khusus dapat membangkitkan motivasi karena peserta didik bisa lebih bersemangat memecahkan berbagai sudut pandang yang saling bertentangan, asalkan mereka dapat melakukannya secara efektif tanpa mengasingkan teman-teman kelasnya. Topik-topik yang sering terjadi miskonsepsi dan menimbulkan konflik kognitif akan lebih menarik dibahas dan dicarikan solusi melalui kegiatan penemuan baik melalui eksperimen maupun diskusi secara berkelompok.

\section{b. Scaffolding}

Scaffolding adalah mekanisme pendukung (oleh orang dewasa berkompeten) yang membantu seorang pembelajar untuk berhasil menyelesaikan suatu tugas dalam zona perkembangan proksimalnya (Ormrod, 2008). Zona perkembangan proksimal (zone of proximal development) atau ZPD, yaitu daerah tingkat perkembangan sedikit di atas daerah perkembangan seseorang saat ini. Menurut Vigotsky (dalam Al Tabany, 2014), proses pembelajaran akan terjadi jika peserta didik bekerja atau menangai tugas-tugas yang belum dipelajari, namun tugas-tugas tersebut masih berada dalam jangkauan mereka.

Kemampuan-kemampuan utama pembelajar usia mahasiswa ini, berada dalam tahap Operasi Formal (teori Piaget tentang perkembangan kognitif), yaitu pemikiran abstrak dan murni simbolis. Menurut teori Piaget ini, permasalahan dalam pembelajaran dapat 
dipecahkan melalui penggunaan eksperimentasi secara sistematis, dan perkembangan kognitif bergantung pada sejauh mana pembelajar aktif memanipulasi dan berinteraksi dengan lingkungannya.

Pada model pembelajaran berbasis konflik kognitif, scaffolding diberikan sesuai dengan kondisi perkembangan mahasiswa tahun pertama. Berbagai fenomena fisika yang dianggap sulit dan sering menjadi miskonsepsi bagi mahasiswa tahun pertama, dijadikan sebagai lembar kerja mahasiswa terutama pada tahap ketiga yaitu penemuan konsep dan persamaannya. Pada tahap ini mahasiswa bekerjasama dalam kelompok dan berdiskusi untuk menemukan konsep beserta persamaan sesuai instruksi dalam LKM. Pada tahap inilah pendidik memberikan scaffolding bagi kelompok mahasiswa yang memerlukannya, walaupun tidak tertutup kemungkinan scaffolding diberikan pada tahap lainnya seperti tahap keempat saat terjadi diskusi kelas.

\section{c. Interaksi Multi Arah}

Interaksi multi arah adalah interaksi dalam proses pembelajaran yang terjadi antar sesama pembelajar dan antar pendidik dengan pembelajar. Interaksi multi arah akan memperkaya pengetahuan dan wawasan pembelajar, melalui berbagai dialog selama proses penemuan, diskusi kelompok dan diskusi kelas. Interaksi multi arah antar sesama mahasiswa dan antar mahasiswa dan dosen juga penting dalam mengungkap miskonsepsi mahasiswa melalui dialog-dialog selama diskusi kelas atau diskusi kelompok. Melalui interaksi ini dosen dapat memberikan masukan dan arahan kepada mahasiswa untuk mengkonstruksi pemahaman mereka dalam membentuk konsep yang benar.

Teori konstruktivisme sosial menegaskan bahwa interaksi sosial (atau interaksi teman sebaya) dan diskusi kelompok merupakan faktor penting dalam perubahan konseptual (e.g., Uzuntiryaki, 2003; Brophy, 1986; Vygotsky, 1978, dalam Baser, 2006). Menurut pendekatan belajar konstruktivistik, pengetahuan dikonstruksi secara sosial (Duit, 2002) dan motivasi 
intrinsik dapat dihasilkan melalui diskusi kelompok, yang berperan penting dalam konstruksi pengetahuan (Pintrich, Marx, \& Boyle, 1993, dalam Baser, 2006).

\section{Prinsip Reaksi}

Prinsip-prinsip reaksi (principles of reaction), merupakan gambaran bagaimana seharusnya pendidik memandang, memperlakukan, dan merespon peserta didik.

\section{a. Student Centered}

Model pembelajaran berbasis konflik kognitif sesuai dengan prinsip pembelajaran student centered, yaitu pembelajaran yang berpusat pada mahasiswa, sedangkan dosen berperan sebagai fasilitator dan motivator. Dosen mengkondisikan mahasiswa untuk terlibat aktif pada setiap tahap atau sintak, mulai dari menjawab soal-soal prakonsepsi/miskonsepsi, membuat hipotesis/jawaban sementara saat penyajian konflik kognitif, melakukan eksperimen dan diskusi kelompok pada tahap penemuan, maupun aktif berdiskusi kelas pada tahap refleksi. Dosen lebih banyak berperan sebagai pembimbing dan pengarah dalam proses pembelajaran, dan memperlakukan mahasiswa layaknya peneliti atau ilmuwan, khususnya dalam tahap penemuan.

\section{b. Procces Oriented}

Model pembelajaran berbasis konflik kognitif berorientasi pada proses pembelajaran, untuk mendapatkan hasil pembelajaran yang diharapkan. Setiap sintak penting untuk memperhatikan proses pembelajaran yang dilakukan mahasiswa, mulai dari proses menyadari kemampuan awal dan miskonsepsi mereka, sampai proses menemukan konsep dan mengubah miskonsepsi mereka. Tugas dosen memfasilitasi dan mengarahkan agar proses-proses dalam pembelajaran berjalan dengan baik. Penekanan pada proses ini bertujuan untuk mengoptimalkan pencapaian pemahaman konsep serta meremediasi miskonsepsi mahasiswa. 


\section{c. Deep Thinking}

Pada model pembelajaran bernuansa konflik kognitif ini, mahasiswa diajak untuk berpikir mendalam (deep thinking), terutama melalui penyajian konflik kognitif. Mahasiswa dihadapkan pada prakonsepsi dan miskonsepsi mereka, kemudian diberikan fenomena berbeda yang bertentangan dengan miskonsepsi mereka untuk memicu konflik kognitif. Mahasiswa akan berpikir mendalam dan memicu rasa ingin tahu tentang fenomena berbeda yang diberikan. Deep thingking dan rasa ingin tahu akan memunculkan semangat dan motivasi untuk melakukan kegiatan penemuan. Proses penemuan yang dilandasi dengan berpikir mendalam akan menyebabkan pembelajaran lebih bermakna dan lebih tahan lama dalam ingatan mahasiswa

\section{Sistem Pendukung}

Sistem pendukung (support system) merupakan segala sarana, bahan, alat, atau lingkungan belajar yang mendukung pembelajaran. Ada 5 sistem pendukung yang diperlukan dalam pelaksanaan model pembelajaran berbasis konflik kognitif ini, yaitu: Rencana Pembelajaran Semester (RPS), Satuan Acara Pembelajaran (SAP), Lembar Kerja Mahasiswa (LKM), Sistem Penilaian, serta kamera untuk merekam kegiatan proses pembelajaran.

\section{a. Rencana Pembelajaan Semester (RPS)}

Permendikbud RI no 49 tahun 2014 tentang Standar Nasional Pendidikan Tinggi, menyatakan bahwa perencanaan proses pembelajaran disusun untuk setiap mata kuliah dan disajikan dalam Rencana Pembelajaran Semester (RPS) yang dikembangkan oleh dosen secara mandiri atau bersama dalam kelompok keahlian suatu bidang ilmu pengetahuan dalam program studi. Sementara itu, Kemenristek Dikti (2016) mengungkapkan 6 prinsip sebagai pertimbangan dalam dalam penyusunan RPS, yaitu: (1) Keterkaitan antara Capaian Pembelajaran Lulusan Program Studi (CPL) dengan Capaian Pembelajaran Mata Kuliah 
(CPMK). (2) CPMK mencakup sikap, pengetahuan, dan keterampilan yang akan dicapai setelah mengikuti perkuliahan mata kuliah tertentu. (3) Kemampuan yang dirumuskan dalam CPMK harus spesifik dan operasional. (4) Rumusan CPMK harus berorientasi kepada mahasiswa atau peserta didik. (5) CPMK harus memandu dosen dalam memilih dan mengembangkan kegiatan pembelajaran. (6) SubCPMK merupakan bagian CPMK yang menggambarkan capaian pembelajaran pada setiap tahapan proses pembelajaran.

Komponen yang harus ada di RPS menurut Kemenristek Dikti (2016), yang merupakan penyempurnaan dari Permendikbud (2014), adalah sebagai berikut:

1. Nama program studi, nama dan kode mata kuliah, semester, sks, nama dosen pengampu;

2. Capaian pembelajaran yang dibebankan pada mata kuliah atau CPMK;

3. Kemampuan akhir yang direncanakan pada tiap tahap pembelajaran untuk memenuhi CPMK disebut SubCPMK;

4. Materi Pembelajaran yang terkait dengan kemampuan yang akan dicapai;

5. Metode/ model/ strategi pembelajaran;

6. Waktu yang disediakan untuk mencapai kemampuan pada tiap tahap pembelajaran;

7. Pengalaman belajar mahasiswa yang diwujudkan dalam deskripsi tugas yang harus dikerjakan oleh mahasiswa selama satu semester

8. Kriteria, indikator, dan bobot penilaian; dan

9. Daftar referensi yang digunakan.

RPS berbasis konflik kognitif disusun berdasarkan sintak model pembelajaran berbasis konflik kognitif. Pengalaman belajar yang diperoleh mahasiswa disesuaikan dengan sintak pada pembelajaran berbasis konflik kognitif, terutama aktivasi prakonsepsi dan miskonsepsi, berpikir mendalam, proses penemuan, presentasi dan diskusi kelas.

\section{b. Satuan Acara Pembelajaran (SAP)}

Satuan Acara Pembelajaran atau SAP merupakan penjabaran dari RPS untuk beberapa pertemuan dengan alokasi waktu yang lebih rinci. SAP diturunkan dari capaian pembelajaran Lulusan dan Kemampuan Akhir Pembelajaran pada RPS, terutama berisi indikator dan 
kegiatan pembelajaran yang lebih rinci di setiap pertemuan. Kegiatan dosen dan Kegiatan mahasiswa beserta alokasi waktu dinyatakan dengan jelas pada SAP.

SAP berbasis konflik kognitif disusun sesuai dengan sintaks pada pembelajaran berbasis konflik kognitif. Peran dosen dan mahasiswa dijelaskan secara rinci sesuai dengan sintak, mulai dengan sintak/tahap aktivasi prakonsepsi dan miskonsepsi, tahap penyajian konflik kognitif, tahap penemuan konsep dan persamaan serta tahap refleksi. Peran dosen sebagai fasilitator dan motivator serta mengarahkan pembelajaran untuk mengaktifkan prakonsepsi mahasiswa, menyajikan konflik kognitif dan memberikan scaffolding saat proses penemuan. Kegiatan mahasiswa lebih utama melakukan eksperimen dan berdiskusi secara berkelompok untuk menemukan konsep dan persamaannya, melakukan presentasi serta diskusi kelas.

\section{c. Lembar Kerja Mahasiswa (LKM)}

LKM atau Lembar Kerja Mahasiswa disusun sesuai dengan sintak model pembelajaran berbasis konflik kognitif (PbKK). LKM berfungsi sebagai panduan kegiatan belajar mahasiswa agar lebih terarah sesuai tahap-tahap dalam model pembelajaran berbasis konflik kognitif. LKM terdiri dari soal-soal konsep sederhana untuk mengaktifkan prakonsepsi dan miskonsepsi mahasiswa, serta fenomena fisika untuk membangkitkan konflik kognitif. LKM juga terdiri dari lembar kerja /kegiatan untuk penemuan konsep dan persamaannya, serta soal evaluasi sebagai refleksi. LKM dilengkapi dengan gambar dan ilustrasi agar lebih menarik dan memudahkan mahasiswa melakukan berbagai kegiatan untuk mencapai pemahaman konsep dan meremediasi miskonsepsi.

Struktur bahan ajar berbentuk LKM (worksheet) terdiri dari enam komponen, yaitu judul, petunjuk belajar, kompetensi dasar, informasi pendukung, langkah kerja dan penilaian (Prastowo, 2011). LKM merupakan materi pembelajaran yang dikemas sedemikian rupa, sehingga mahasiswa dapat mempelajari materi tersebut secara mandiri. LKM berisi tugas- 
tugas pembelajaran yang harus dikerjakan mahasiswa yang mengacu pada kompetensi yang harus dicapai. Dalam melakukan tugas-tugas LKM, mahasiswa juga memerlukan buku referensi yang terkait dengan tugas tersebut.

\section{d. Peralatan Eksperimen}

Pada pelaksanaan model pembelajaran berbasis konflik kognitif diperlukan peralatan untuk eksperimen, baik eksperimen sederhana dengan peralatan yang mudah diperoleh di sekitar mahasiswa, maupun eksperimen menggunakan set peralatan yang lebih canggih buatan industri. Kegiatan eksperimen penting dilakukan dalam pelaksanaan model pembelajaran ini agar mahasiswa dapat mongkonstruksi konsep dengan cara 'mengalami' sendiri, tidak hanya membayangkan suatu yang abstrak. Konsep-konsep dan proses dalam fisika yang bisa diamati maka dapat dilakukan eksperimen secara langsung melalui bantuan peralatan eskperimen, namun untuk konsep abstrak tententu yang tidak bisa diamati langsung, baik karena ukurannya yang makro maupun mikro atau eksperimen yang sulit dilakukan, maka konstruksi konsep dapat dilakukan melalui model animasi atau ilustrasi.

\section{e. Alat Penilaian}

Alat evaluasi atau penilaian pada model pembelajaran berbasis konflik kognitif berupa kumpulan soal tentang konsep-konsep fisika untuk mengetahui pemahaman konsep dan miskonsepsi yang terjadi pada mahasiswa. Selain itu, soal-soal hitungan juga diberikan kepada mahasiswa untuk mengetahui pemahaman mereka tentang persamaan-persamaan fisika yang menyatakan hubungan antar konsep. Alat evaluasi ini disusun oleh dosen berdasarkan studi literatur dan pengalaman dalam pembelajaran tentang konsep-konsep sulit yang dialami mahasiswa serta konsep yang sering menjadi miskonsepsi. Alat penilaian terdiri dari tes konsep fisika yang terkait dengan materi serta soal-soal hitungan untuk melihat pemahaman mahasiswa terhadap persamaan-persamaan fisika. 
Sistem pendukung model dapat dilengkapi dengan kamera untuk mendokumentasikan kegiatan pembelajaran serta sebagai alat bantu untuk mengamati aktivitas mahasiswa dalam melakukan kegiatan di setiap tahap /sintak pembelajaran. Kamera efektif untuk merekam dialog-dialog selama proses pembelajaran terutama pada kegiatan diskusi kelompok dan diskusi kelas untuk membantu mengungkap pemahaman konsep dan miskonsepsi mahasiswa.

\section{DAMPAK INSTRUKSIONAL}

Dampak instruksional (instructional effects) merupakan hasil belajar yang diperoleh langsung berdasarkan tujuan pembelajaran yang disasar. Pada model pembelajaran berbasis konflik kognitif ini terdapat dua tujuan yang hendak dicapai secara langsung yaitu meningkatkan pemahaman konsep dan meremediasi miskonsepsi mahasiswa.

\section{a. Meningkatkan Pemahaman Konsep}

Tujuan utama pelaksanaan model pembelajaran berbasis konflik kognitif ini adalah untuk meningkatkan pemahaman konsep mahasiswa. Hasil belajar mahasiswa dalam bidang fisika seringkali lebih rendah dibanding hasil belajar di bidang MIPA lainnya. Mahasiswa sulit memahami konsep-konsep fisika walaupun mereka terampil menggunakan persamaan fisika. Persamaan fisika mereka hafal, namun tidak mengetahui makna fisis yang terkandung dalam persamaan fisika tersebut. Model ini diawali dengan aktivasi prakonsepsi mahasiswa agar dosen mengetahui kemampuan awal tentang konsep fisika mereka, kemudian dosen berpijak pada prakonsepsi ini dalam melakukan pembelajaran untuk meningkatkan pemahaman konsep mahasiswa.

\section{b. Meremediasi Miskonsepsi}

Permasalahan pembelajaran fisika tidak hanya tentang rendahnya pemahaman konsep, namun mahasiswa juga sering mengalami miskonsepsi. Banyak penelitian yang mengungkapkan bahwa siswa maupun mahasiswa mengalami miskonsepsi hampir di setiap 
bidang fisika. Demikian juga berdasarkan pengalaman dalam pembelajaran, para dosen juga menemukan miskonsepsi terjadi pada mahasiswa. Model pembelajaran bernuansa konflik kognitif ini memberikan langkah langkah untuk meremediasi miskonsepsi, mulai dari aktivasi miskonsepsi, penyajian konflik kognitif, melakukan penemuan untuk mengkonstruksi konsep baru, serta refleksi. Model ini memfasilitasi terjadinya perubahan konseptual pada mahasiswa, disamping juga meningkatkan pemahaman konsep mahasiswa.

\section{DAMPAK PENGiRing}

Dampak pengiring (nurturant effects) adalah hasil belajar di luar tujuan pembelajaran yang disasar. Ada dua hasil belajar yang menjadi dampak pengiring dalam model ini, yaitu: meningkatkan sikap positif mahasiswa terhadap belajar fisika serta meningkatkan minat belajar fisika.

\section{a. Meningkatkan Sikap Positif terhadap Belajar Fisika}

Berdasarkan pengalaman dan hasil penelitian, fisika dianggap sebagai pembelajaran yang sulit oleh sebagian besar pembelajar, baik oleh siswa SMA maupun mahasiswa. Olusola \& Rotimi (2012) menyatakan bahwa fisika dianggap sebagai pelajaran yang sulit bagi siswa mulai dari sekolah menengah sampai ke universitas dan juga oleh orang dewasa dalam pendidikan pascasarjana. Olusola juga menemukan bahwa penyebab buruknya kinerja mahasiswa dalam belajar fisika adalah karena kurangnya informasi, kurangnya rasa percaya diri, ketidakmampuan untuk memecahkan permasalahan fisika secara benar menggunakan rumus yang tepat, dan tidak mampu melihat relevansi fisika dengan kegiatan sehari-hari di masyarakat.

Langkah-langkah dalam model pembelajaran berbasis konflik kognitif mengarahkan mahasiswa mengenali pengetahuan awal dan menyadari miskonsepsi mereka. Penyajian konflik kognitif akan memberikan suasana ilmiah yang baik dan memicu rasa ingin tahu 
terhadap suatu fenomena fisika melalui proses berpikir mendalam. Selanjutnya proses penemuan melalui kegiatan eksperimen dan diskusi untuk meningkatkan pemahaman konsep serta meremediasi miskonsepsi mahasiswa. Seluruh rangkaian kegiatan dalam model pembelajaran berbasis konflik kognitif menjadikan pembelajaran fisika lebih bermakna dan menyenangkan terutama dalam memahami konsep-konsep dan persamaan fisika yang selama ini dianggap sulit. Dengan demikian mahasiswa akan bersikap posistif terhadap belajar fisika dan dapat memahami konsep-konsep yang terkandung dalam persamaan fisika.

\section{b. Meningkatkan Motivasi Instrinsik}

Ada dua jenis motivasi dalam belajar, yaitu motivasi intrinsik dan motivasi ekstrinsik. Motivasi instrinsik adalah dorongan yang muncul dari dalam diri sesorang, sedangkan motivasi estrinsik adalah motivasi yang muncul dari luar diri orang tersebut. Dorongan belajar yang muncul dari dalam diri seseorang lebih baik dari pada dorongan belajar yang disebabkan oleh orang lain atau oleh faktor luar lainnya. Model pembelajaran berbasis konflik kognitif melalui sintak pembelajarannya dapat menimbulkan motivasi intrinsik bagi mahasiswa. Aktivasi prakonsepsi dan miskonsepsi dilanjutkan dengan penyajian fenomena konflik kognitif dapat memicu rasa ingin tahu mahasiswa, dan menimbulkan semangat untuk menemukan konsep yang benar. Dahar (2011) mengungkapkan bahwa hal yang berlawanan dapat menimbulkan suatu kesangsian yang merangsang para siswa untuk menyelidiki suatu masalah, menyusun hipotesis dan mencoba menemukan konsep dan prinsip yang mendasari masalah tersebut.

Pada tahap penemuan, motivasi intrinsik akan muncul melalui kegiatan eksplorasi pada saat mahasiswa melakukan eksperimen dan diskusi kelompok. Bruner menyatakan pengalaman mahasiswa yang berpartisipasi aktif dalam menghadapi alamya pada belajar penemuan akan memunculkan motivasi (Dahar, 2011). Bruner percaya bahwa, sebagai konsekuensi dari keberhasilan penemuan, siswa akan menerima sensasi menyenangkan 
sebagai seorang intelektual, ini merupakan suatu reward intrinsik atau reward yang memuaskan diri siswa tersebut (Carin, 2007). Proses penemuan terbimbing membantu mahasiswa menjadi lebih otonom, mandiri, dan bertanggung jawab terhadap pembelajaran mereka. Mahasiswa akan lebih termotivasi ketika mereka belajar dengan menemukan sendiri, bukan dari mendengar dari dosen. Melalui proses penemuan dalam pembelajaran berbasis konflik kognitif $(\mathrm{PbKK})$ ini mahasiswa memanipulasi lingkungan mereka secara aktif dan mendapat kepuasan setelah berhasil menemukan solusi dan mengatasi masalah. 


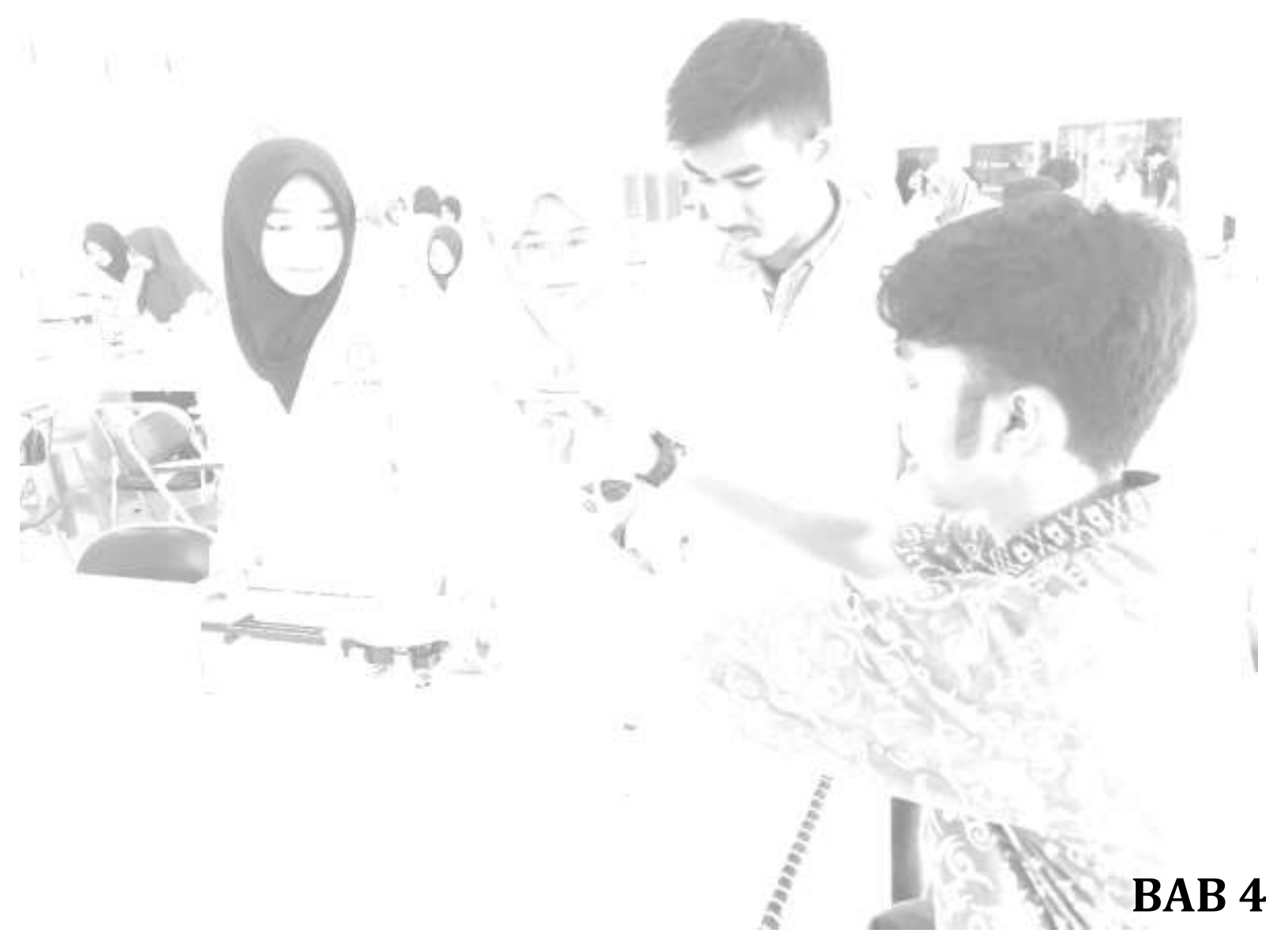

\section{Petunjuk Pelaksanaan Model PbKK}

\section{Petunjuk Pelaksanaan untuk Dosen}

Kegiatan yang dilakukan dosen sebelum melaksanakan model pembelajaran berbasis Konflik Kognitif

a. Dosen mempelajari RPS dan SAP berbasis konflik kognitif

b. Dosen mengidentifikasi konsep sulit dan miskonsepsi yang sering terjadi pada materi yang akan diajarkan.

c. Dosen menyiapkan beberapa fenomena fisika yang akan mengcounter miskonsepsi untuk memunculkan konflik pada kognitif mahasiswa.

d. Dosen menyiapkan LKM berbasis konflik kognitif terkait materi yang akan diajarkan.

e. Dosen mengatur ketersediaan peralalatan eksperimen sesuai materi dalam LKM 
Kegiatan dosen pada saat pelaksanaan Model pembelajaran berbasis Konflik Kognitif.

a. Dosen mengacu pada SAP dalam pelaksanaan model pembelajaran berbasis konflik kognitif

b. Mahasiswa bekerja/ belajar menggunakan LKM berbasis konflik kognitif.

c. Pada tahap pertama (Aktivasi Prakonsepsi dan Miskonsepsi), LKM diberikan secara terpisah. LKM tahap pertama ini dikerjakan secara individu oleh mahasiswa untuk mengetahui dan mengaktifkan prakonsepsi dan miskonsepsi mereka.

d. Setelah dosen mengetahui secara umum kondisi prakonsepsi dan miskonsepsi mahasiswa, dosen menyajikan fenomena konflik kognitif yang bertentangan dengan miskonsepsi mereka dan melakukan tanya jawab untuk membangkitkan konflik kognitif.

e. Dosen membagikan LKM tahap selanjutnya secara keseluruhan. Mahasiswa mengerjakan LKM sesuai petunjuk (individu atau berkelompok).

f. Dosen mengamati dan memberikan scaffolding bagi mahasiswa yang membutuhkan.

g. Dosen memberikan balikan (refleksi) terhadap hasil kerja mahasiswa (saat diskusi kelas dan evaluasi).

h. Dosen mengingatkan waktu untuk setiap fase secara disiplin

i. Dosen harus bersikap ramah untuk mendukung sikap positif serta motivasi mahasiswa dalam belajar fisika.

\section{Sintak dan Kegiatan Pembelajaran dalam Penerapan Model}

Tabel berikut ini menjelaskan sintak model pembelajaran berbasis konflik kognitif beserta kegiatan dosen dan kegiatan mahasiswa. Dosen menggunakan uraian sintak ini sesuai dengan materi pembelajaran yang tepat dan relevan dengan penerapan model pembelajaran 
berbasis konflik kognitif, khususnya materi pembelajaran yang sulit dipahami dan banyak ditemui miskonsepsi pada mahasiswa.

Sintak dan Kegiatan dalam Model Pembelajaran Berbasis Konflik Kognitif

\begin{tabular}{|c|c|c|}
\hline Tahap & Kegiatan Dosen & Kegiatan Mahasiswa \\
\hline $\begin{array}{l}\text { Aktivasi } \\
\text { Prakonsepsi } \\
\text { dan } \\
\text { Miskonsepsi }\end{array}$ & 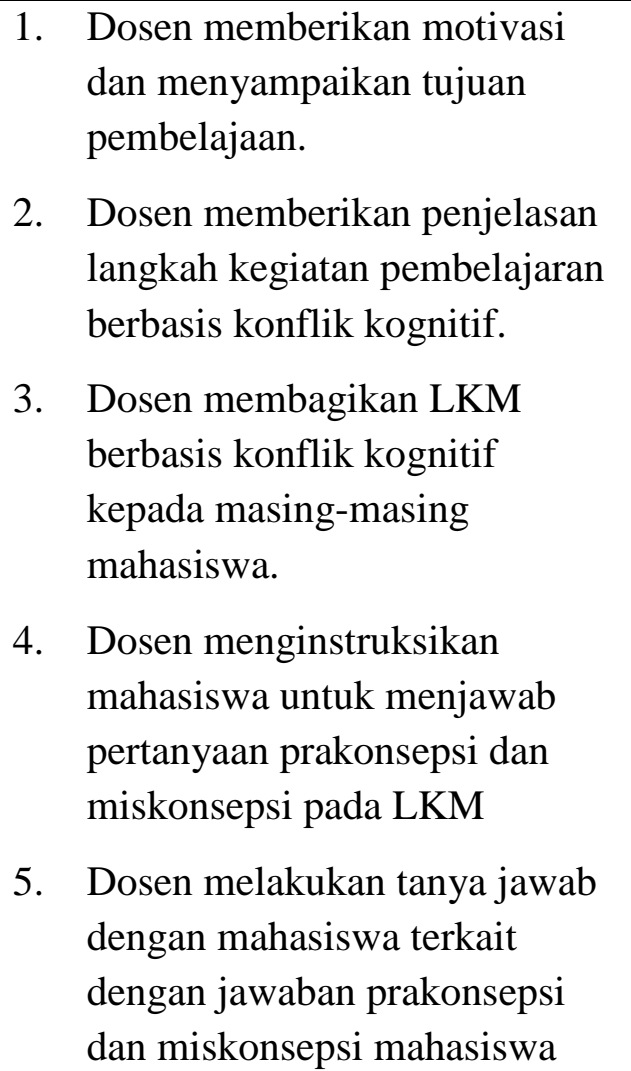 & $\begin{array}{l}\text { 1. } \begin{array}{l}\text { Mahasiswa } \\
\text { memperhatikan } \\
\text { penjelasan dosen dan } \\
\text { mencatat poin-poin } \\
\text { penting. }\end{array} \\
\text { 2. Mahasiswa menanggapi } \\
\text { penjelasan dosen dan } \\
\text { menanyakan hal yang } \\
\text { belum dipahami. } \\
\text { 3. Secara individu, } \\
\text { mahasiswa menjawab } \\
\text { pertanyaan prakonsepsi } \\
\text { dan miskonsepsi pada } \\
\text { LKM. } \\
\text { Mahasiswa menanggapi } \\
\text { pertanyaan dosen terkait } \\
\text { jawaban prakonsepsi dan } \\
\text { miskonsepsi mereka. }\end{array}$ \\
\hline $\begin{array}{l}\text { Penyajian } \\
\text { Fenomena } \\
\text { Konflik } \\
\text { Kognitif }\end{array}$ & $\begin{array}{l}\text { 6. } \begin{array}{l}\text { Dosen memberikan fenomena } \\
\text { konflik kognitif sesuai } \\
\text { miskonsepsi mahasiswa }\end{array} \\
\text { 7. Dosen menginstruksikan } \\
\text { mahasiswa untuk membaca } \\
\text { fenomena konflik kognitif pada } \\
\text { LKM dan menuliskan jawaban } \\
\text { sementara mereka. }\end{array}$ & $\begin{array}{ll}\text { 4. } & \text { Mahasiswa berpikir } \\
\text { mendalam menanggapi } \\
\text { fenomena konflik } \\
\text { kognitif yang diberikan } \\
\text { dosen. } \\
\text { 5. Mahasiswa membaca } \\
\text { fenomena konflik } \\
\text { kognitif dalam LKM dan } \\
\text { menuliskan jawaban } \\
\text { sementara mereka. }\end{array}$ \\
\hline
\end{tabular}




\begin{tabular}{|c|c|c|}
\hline TAHAP & KEGIATAN DOSEN & KEGIATAN MAHASISWA \\
\hline $\begin{array}{l}\text { Penemuan } \\
\text { Konsep dan } \\
\text { Persamaan }\end{array}$ & 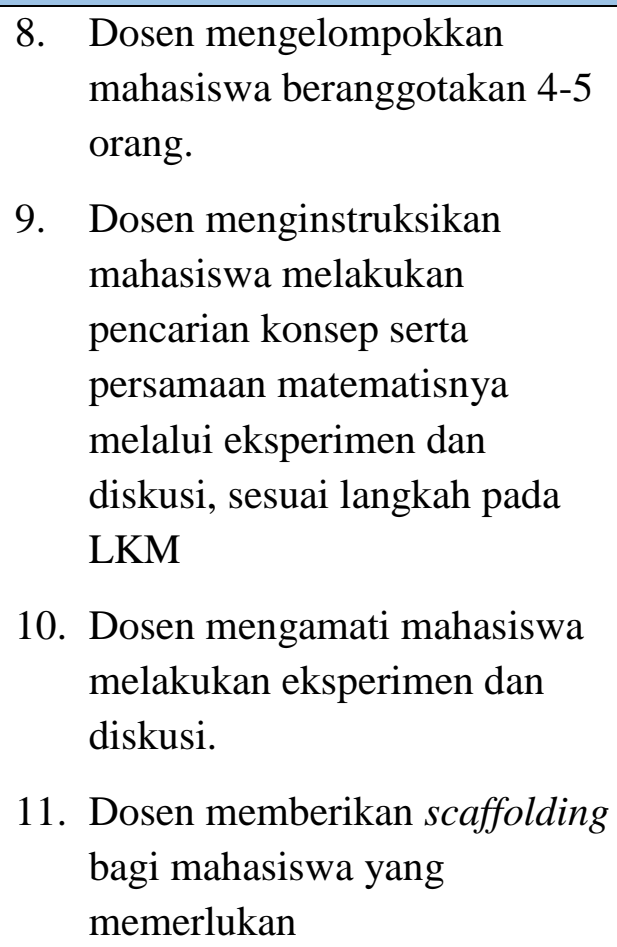 & 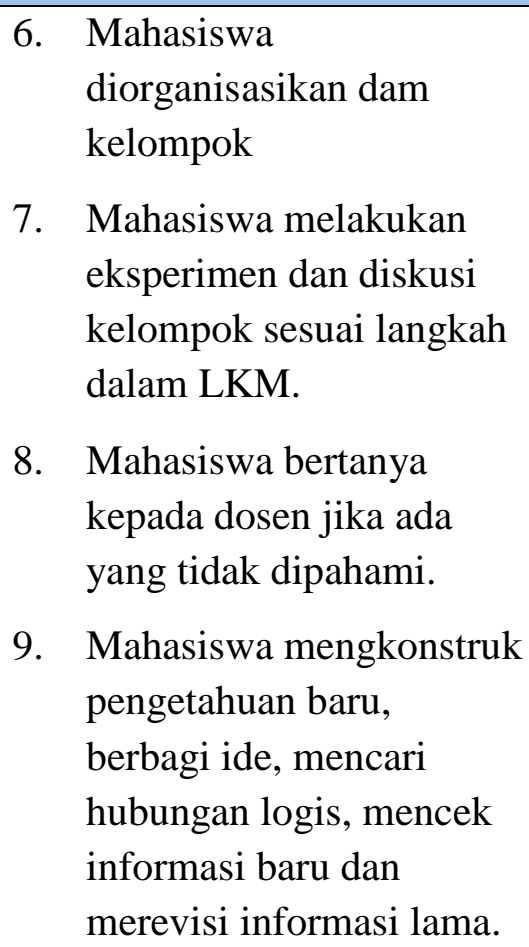 \\
\hline Refleksi & $\begin{array}{l}\text { 12. Dosen menentukan salah satu } \\
\text { kelompok untuk } \\
\text { mempresentasikan hasil kerja } \\
\text { kelompok } \\
\text { 13. Dosen memimpin diskusi kelas } \\
\text { 14. Dosen menginstruksikan } \\
\text { kepada setiap mahasiswa untuk } \\
\text { menyelesaikan soal evaluasi } \\
\text { pada LKM. } \\
\text { 15. Dosen mereview dan } \\
\text { memberikan refleksi terhadap } \\
\text { hasil evaluasi mahasiswa dan } \\
\text { menyelesaian miskonsepsi } \\
\text { mereka. }\end{array}$ & $\begin{array}{l}\text { 10. Salah satu kelompok } \\
\text { mahasiswa } \\
\text { mempresentasikan hasil } \\
\text { kerja kelompok } \\
\text { 11. Mahasiswa melakukan } \\
\text { diskusi kelas dengan } \\
\text { bimbingan dosen. } \\
\text { 12. Mahasiswa } \\
\text { mengemukakan ide, } \\
\text { berbagi ide, } \\
\text { merestrukturisasi ide. } \\
\text { 13. Mahasiswa } \\
\text { menyelesaikan soal } \\
\text { evaluasi pada LKM } \\
\text { secara individu }\end{array}$ \\
\hline Penutup & $\begin{array}{l}\text { 16. Dosen membimbing mahasiswa } \\
\text { menyimpulkan pembelajaran. } \\
\text { 17. Dosen memberikan pengarahan } \\
\text { tugas untuk pertemuan berikutnya }\end{array}$ & $\begin{array}{l}\text { 1. Mahasiswa melalui } \\
\text { bimbingan dosen } \\
\text { menyimpulkan pembelajaran. } \\
\text { 2. Mahasiswa mencatat tugas } \\
\text { untuk pertemuan berikutnya. }\end{array}$ \\
\hline
\end{tabular}




\section{REFERENSI}

Al Arief, M A, Suyono. (2012) Penerapan Strategi Konflik Kognitif Dalam Mengatasi Miskonsepsi Siswa Pada Materi Pokok Larutan Eletrolit Dan Non Eletrolit Siswa Kelas X SMA Khadijah Surabaya. Prosiding Seminar Nasional Kimia Unesa 2012 - ISBN : 978-979-028-550-7 Surabaya, 25 Pebruari 2012

Al Tabany, Trianto I Badar. 2014. Mendesain Model Pembelajaran Inovatif, Progresif dan Kontekstual. Jakarta: Kencana

Baharuddin \& Esa Nur Wahyuni. 2015. Teori Belajar \& Pembelajaran. Yogyakarta: Ar-Ruzz Media.

Baser, M .2006. "Fostering conceptual change by cognitive conflict based instruction on student understanding of heat and temperature concepts". Eurasia Journal of Mathematics, Science and Technology Education. 2(2). 96-114.

Carin, Arthur A. 1997. Teaching Science Through Discovery, Eighth edition. Pearson Prentice Hall: New Jersey, Columbus Ohio.

Dahar, Ratna Wilis. 2011. Teori-Teori Belajar dan Pembelajaran. Jakarta: Erlangga.

Joyce, B., \& Weil, M., (1980). Models of teaching. Second edition. Englewood Cliffs, NJ: Prentice-Hall.

Joyce, Bruce, M. Weill, E. Calhoun. 2011. Models of Teaching. Model-Model Pengajaran (edisi delapan). Penerjemah Achmad Fawaid dan Ateilla Mirza. Yogyakarta: Pustaka Pelajar.

Kabaca T, Z Karadag, M Aktumen. (2011). Misconception, cognitive conflict and conceptual changes in geometry: a case study with pre-service teachers. Mevlana International Journal of Education (MIJE) Vol. 1(2), pp.44-55, 30 December, 2011

Kemenristek Dikti. 2016. Panduan Pengembangan Kurikulum Pendidikan Guru. Direktorat Pembelajaran. Direktorat Pembelajaran dan Kemahasiswaan. Kementrian Riset, Teknologi dan Pendidikan Tinggi.

Liang, S. 2016. "Teaching the concept of limit by using conceptual conflict strategy and Desmos graphing calculator". International Journal of Research in Education and Science (IJRES), 2(1), 35-48.

Mufit, Fatni. (2016) A Study about Understanding the Concept of Force and Attitude towards Learning Physics on First-Year Students in the Course of General Physics; as Preliminary Investigation in Development Research. Proceeding of SEA-DR (South East Asia- Design/Development Research) Conference 2016, International Conference: April, $17^{\text {th }}-18^{\text {th }}$ 2016. Universitas Negeri Padang, West Sumatera Indonesia. ISBN: 978602-19877-5-9.

Mosik, P. Maulana. (2010). Usaha Mengurangi Terjadinya Miskonsepsi Fisika melalui Pembelajaran dengan Pendekatan Konflik Kognitif. Jurnal Pendidikan Fisika Indonesia (JPFI) 6 (2010) 98-103.

Olusola, OO, Rotimi.CO. .2012. "Attitudes of Students towards the Study of Physics in College of Education Ikere Ekiti, Ekiti State, Nigeria". American International 
Journal of Contemporary Research Vol. 2 No. 12; December 2012. (http:// www.aijcrnet.com/ journals/ Vol_2_No_12_December_2012/9.pdf)

Ormrod. J.E. 2009. Psikologi Pendidikan; alih bahasa Triwibowo. J.S. Jakarta: Erlangga.

Peratuarn Menteri Pendidikan Dan Kebudayaan Republik Indonesia No 49 Tahun 2014 Tentang Standar Nasional Pendidikan Tinggi. (http://faperta.ugm.ac.id/ 2014/site/ fokus /pdf/permen_tahun2014_nomor 049. pdf)

Prastowo, Andi .2011. Panduan Kreatif Membuat Bahan Ajar Inovatif. Yogyakarta: Diva Press.

Reigeluth, Charles.M. 1999. Instructional-Design Theories and Models. An Overview of Their Current Status. Mahwah, New Jersey, London: Lawrence Erlbaum Associates, Publisher.

Ronis, Diane. 2001. Problem-Based Learning for Math and Science, Integrating Inquiry and the Internet. Skylight Training and Publishing Inc. Arlington Heights, Illinois, USA.

Sadia, I Wayan .2014. Model-Model Pembelajaran Sains Konstruktivistik. Jogyakarta: Graha Ilmu.

Suparno, Paul .2013. Miskonsepsi dan Perubahan Konsep dalam Pendidikan Fisika. Jakarta: PT. Gramedia Widiasarana Indonesia.

Suwarto. 2013. Pengembangan Tes Diagnostik dalam Pembelajaran. Panduan Praktis bagi Pendidik dan Calon Pendidik. Yogyakarta: Pustaka Pelajar.

Tarigan, Simson .2013. "Menginduksi Perubahan Konsep Dengan Mempertimbangkan Pengetahuan Awal Siswa Sebagai Salah Satu Model Pembelajaran IPA". Disertasi UPI Bandung, online (Resipotery @upi).

Wilardjo, Liek .2009. "Secercah Pandangan tentang Pengajaran Sains". dalam P.J.Suwarno (Eds). Pendidikan Sains yang Humanistis.(hal: 50-94). Yogyakarta: Kanisius.

Kabaca T, Z Karadag, M Aktumen. (2011). Misconception, cognitive conflict and conceptual changes in geometry: a case study with pre-service teachers. Mevlana International Journal of Education (MIJE) Vol. 1(2), pp.44-55, 30 December, 2011 